\title{
BIO-SYSTEM IN HIGH CONCENTRATION ORGANIC WASTEWATER TREATMENT
}

\author{
CHENG, X.-X. - LI, G.-C.*-PIAO, C.-X.* \\ Department of Agricultural Resources and Environment, Agricultural College of Yanbian \\ University, Yanji, P. R. China \\ *Corresponding authors \\ e-mail: gcli@ybu.edu.cn, cxpiao@ybu.edu.cn \\ (Received 21 ${ }^{\text {st }}$ Jun 2018; accepted $3^{\text {rd }}$ Sep 2018)
}

\begin{abstract}
In this paper we studied a bio-system which could be applied to the treatment of high concentration organic wastewater and aimed at increasing its efficiency by laboratory scale wastewater treatment reactors. The reactors were divided into control reactor, reactor one (Adding Pellet bacteria and pumice) and reactor two (Adding Pellet and pumice). The reactors had two patterns of long aeration, and intermittent aeration which could be divided into four stages. The $\mathrm{COD}, \mathrm{NH}_{3}-\mathrm{N}, \mathrm{NO}_{3}-\mathrm{N}$, Total Nitrogen (TN), Total Phosphorus (TP) were measured. The experimental results showed that the removal abilities of COD, $\mathrm{NH}_{3}-\mathrm{N}, \mathrm{NO}_{3}-\mathrm{N}, \mathrm{TN}$ and TP of reactor one and two were better than those of the control reactor in two modes. Above all, the reactor one and two increased the removal efficiency of high concentration organic wastewater. The reactor two achieved the best removal efficiency of high concentration organic wastewater. The best effect was reached when the operating condition was $1 \mathrm{~h} 20 \mathrm{~min} / 1 \mathrm{~h} 20 \mathrm{~min}$ (Aeration / Stopping aeration), and the average removal rates were enhanced by 3\%, 21\%, 54\%, 21\%, $25 \%$ respectively.
\end{abstract}

Keywords: pellet, pumice, reactor, intermittent aeration, water quality analysis

\section{Introduction}

China is a country with serious water shortage, and the per capita water consumption is very low, accounting for only 1/4 of the world's per capita level (Chen et al., 2002):. In addition, serious problems such as serious waste and serious pollution in China's water resources still exist. For a long time, water pollution had been the most prominent problem in the national environmental safety (Zhang, 2014). According to the national environmental statistics bulletin, the total amount of wastewater discharge in 2015 was 735.3 million tons, including 199.5 tons of industrial wastewater and 535.2 million tons of urban sewage discharge. It can be seen that industrial wastewater accounts for about $27 \%$ of the national wastewater discharge, and industrial wastewater was mainly organic wastewater with high concentration. Additionally, the slaughterhouse wastewater and livestock wastewater have been high concentration organic wastewater and therefore the treatment of high concentration organic wastewater was very significant in the process of sewage treatment.

High concentration organic wastewater generally refers to the wastewater whose COD was more than $2000 \mathrm{mg} / \mathrm{L}$ (Wang and Liao, 2011), which was mainly discharged from papermaking, leather, food and slaughterhouse. As the high concentration, organic wastewater contains a large number of organic compounds such as carbohydrates, fat, protein, cellulose and many organic pollutants which were extremely difficult to decompose and contained high levels of toxicity, it would cause serious water environmental pollution (Chen et al., 2008), even endangering human health if they were not treated properly and discharged directly. It has been one of the most difficult 
problems in the field of environmental protection research in China and abroad because it caused wide range and high degree of pollution (Huang et al., 2004).

Currently, there have been mainly three kinds of technologies commonly used for high concentration organic wastewater treatment, which were chemical treatment, physicochemical treatment and biological treatment. At present, the two which commonly used chemical treatment technologies were Incineration (Bie et al., 2000) and Catalytic wet oxidation (Sun et al., 1999; Du et al., 1997a, b) respectively. The two widely used physical extraction technologies included complexation extraction (Yang and Dai, 1997; Rousseau, 1987) and Pulsed extraction (He et al., 2002; Zhu et al., 2001). Biological treatment technology mainly uses the decomposition of microbes, which means that the microorganism decomposes the polluted material in the wastewater as its own nutrition and energy, and finally realizes sewage purification (Zhao et al., 2003). In recent years, biological treatment technology has played an extremely important role in the treatment of high concentration organic wastewater, because it accorded with the idea of sustainable development (Ren, 2000). At present, the activated sludge process has become the main treatment technology of various organic wastewaters (Li and Yang, 2002; Lu et al., 2001). Complete Mixing Activated Sludge Process was one of the most common wastewater treatment processes in an aerobic activated sludge process. It has many advantages. First of all, it can resist a high sludge load. Secondly, the automatic reflux of sludge can be realized. Thirdly, it is easy to manage and the delayed aeration can be reached by prolonging the age of sludge. Last but not least, the primary sedimentation tank can be saved (Wang and Sun, 1995). However, when to use the activated sludge process, especially the traditional activated sludge process to treat high concentration organic wastewater, the phenomenon that the water quality of the effluent was poor such as the high content of $\mathrm{N}$ and $\mathrm{P}$ will always happen. The Sequencing Batch Reactor Activated Sludge Process (SBR) was developed later and it greatly made up the deficiency of the activated sludge process. Therefore, it was widely used in the treatment of high concentration organic wastewater (Ganigué et al., 2012; Liu et al., 2015; Jena et al., 2016). The technology of SBR has expressed many strengths. First of all, the most prominent feature of SBR is the realization of intermittent aeration. Secondly, the precipitation performance of SBR is great and the push flow state is ideal. Thirdly, it can efficiently remove organic matter, there is no need to increase the performance to involve more reactors ( $\mathrm{Wu}, 2017)$. Additionally, it can also provide anaerobic, anoxic and aerobic living environment for microorganism and this kind of environment was beneficial to improve the treatment efficiency of refractory wastewater including the removal of $\mathrm{N}$ and $\mathrm{P}$. Finally, due to the large gradient of substrate concentration in the SBR system and the alternating between aerobic and anoxic (or anaerobic); the breeding of filamentous bacteria can be inhibited effectively, and the sludge bulking was controlled (Liu and Meng, 2008).

In addition to these traditional biological processes, there are also some derived processes such as the Reactor-Bio-System (RBS). RBS system was a relatively advanced high concentration organic wastewater treatment technology developed in Japan (Jiang et al., 2008; Zhai, 2014). RBS technology imitates nature and achieves the artificial induction and screening of microorganisms in the soil in the soil reaction by adding many small particles filled with humic precursors and some silica, for which the soil reaction can provide a large number of soil dominant bacteria and highly active nutrients for the whole sewage treatment system and then enhance the efficiency of sewage treatment. Therefore, RBS technology was also named "natural purification." 
RBS technology uses the biochemical effect of highly active facultative soil bacteria to purify sewage, and it embodies many advantages when compared with the traditional activated sludge process. It has six major advantages (Jiang et al., 2008). Firstly, it can be directly used to treat high concentration organic wastewater and the influent does not need to be diluted. Secondly, it can ensure SS concentration in the sewage treatment system. Thirdly, it has a high efficiency. Fourthly, it performs well in removing $\mathrm{N}$ and P. Fifthly, it has a good sludge characteristic. Lastly, it can effectively inhibit odor. The COD in the sewage discharged from the original field of Anshan's Tianyi pig farm was $2000 \mathrm{mg} / \mathrm{L}$, and the $\mathrm{BOD}_{5}$ reached $500 \mathrm{mg} / \mathrm{L}$. The sewage was one kind of high concentration organic wastewater, and it would cause serious pollution to the receiving water. Tianyi pig farm introduced RBS technology from Japan to discharge sewage and formally put it into using in June 2001. The operation results showed that after the application of this technology, the concentrations of $\mathrm{COD}$ and $\mathrm{BOD}_{5}$ in the sewage were obviously reduced, and the water quality of the effluent reached the standard of sewage discharge (Zhao, 2002). Above all, the application of RBS in Tianyi pig farm achieved good results.

This experiment applied laboratory scale wastewater biological treatment reactor to the treatment of high concentration organic wastewater with a bio-system, which was used with pellet and pumice.

\section{Materials and methods}

\section{Materials}

Pellet and Pellet (bacteria) for bio-system were columnar materials made in the laboratory. Pumice was purchased from the Tianhe pumice factory in Songjiang River town of Fusong county.

Production method of Pellet: Mix peat soil (pH 5.47) $40 \mathrm{~g}$, bentonite $20 \mathrm{~g}$, calcium alginate $0.6 \mathrm{~g}$ and cement $15 \mathrm{~g}$ in a beaker, then spray a certain amount of distilled water into the beaker. The cultivation (Bacillus CGMCC13429: CICC23692: CICC20666 = 1: 1: 1) for production pellet (bacteria) was sprayed in distilled water $\left(\geq 10^{8} \mathrm{cfu} / \mathrm{ml}\right)$.

\section{Production of artificial wastewater}

The artificial wastewater was made from glucose, $\mathrm{NH}_{4} \mathrm{Cl}, \mathrm{KNO}_{3}$, urea, $\mathrm{KH}_{2} \mathrm{PO}_{4}$ and deionized water. The concentration range of COD was $2000 \sim 3000 \mathrm{mg} / \mathrm{L} ; \mathrm{NH}_{3}-\mathrm{N}$ was $30 \sim 70 \mathrm{mg} / \mathrm{L} ; \mathrm{NO}_{3}-\mathrm{N}$ was $10 \sim 15 \mathrm{mg} / \mathrm{L} ; \mathrm{TN}$ was $100 \sim 140 \mathrm{mg} / \mathrm{L}$; TP was $30 \sim$ $40 \mathrm{mg} / \mathrm{L} .1 \mathrm{ml}$ trace element solution was added to $25 \mathrm{~L}$ artificial wastewater in order to provide microelement for microorganism.

Trace element solution ( $\mathrm{Li}$ et al., 2007): $\mathrm{MoO}_{3} 1.0 \mathrm{mg}, \mathrm{ZnSO}_{4} \cdot 7 \mathrm{H}_{2} \mathrm{O} 7.0 \mathrm{mg}$, $\mathrm{CuSO}_{4} \cdot 5 \mathrm{H}_{2} \mathrm{O} 0.5 \mathrm{mg}, \mathrm{H}_{3} \mathrm{BO}_{3} 1.0 \mathrm{mg}, \mathrm{MnSO}_{4} \bullet 5 \mathrm{H}_{2} \mathrm{O} 1.0 \mathrm{mg}, \mathrm{CoCl}_{2} \bullet 6 \mathrm{H}_{2} \mathrm{O} 1.0 \mathrm{mg}$, $\mathrm{NiSO}_{4} \cdot 7 \mathrm{H}_{2} \mathrm{O} 1.0 \mathrm{mg}, 1 \mathrm{~L}$ deionized water.

\section{Experimental reactor}

The laboratory scale bioreactor was made of organic glass (Figure 1). It consisted of three parts including aeration tank, sedimentation tank and reaction tank (consist of the bio-system with pellet and pumice). The effective volumes of the aeration tank, the sedimentation tank and the reaction tank were $48 \mathrm{~L}, 11 \mathrm{~L}, 15 \mathrm{~L}$ respectively. Water 
distribution bucket was used to fill the artificial wastewater with a total volume of $25 \mathrm{~L}$. The mechanical agitator was used to mix. The peristaltic pump was used to control influent and sludge reflux and the air lift pump was used to control sludge return. The electromagnetic air pump was used to offer aeration for aeration tank and reaction tank. The quantity of influent, sludge return was $8 \mathrm{~L} / \mathrm{d}, 3 \mathrm{~L} / \mathrm{d}$ and the overall HRT of reactor was 6 days.

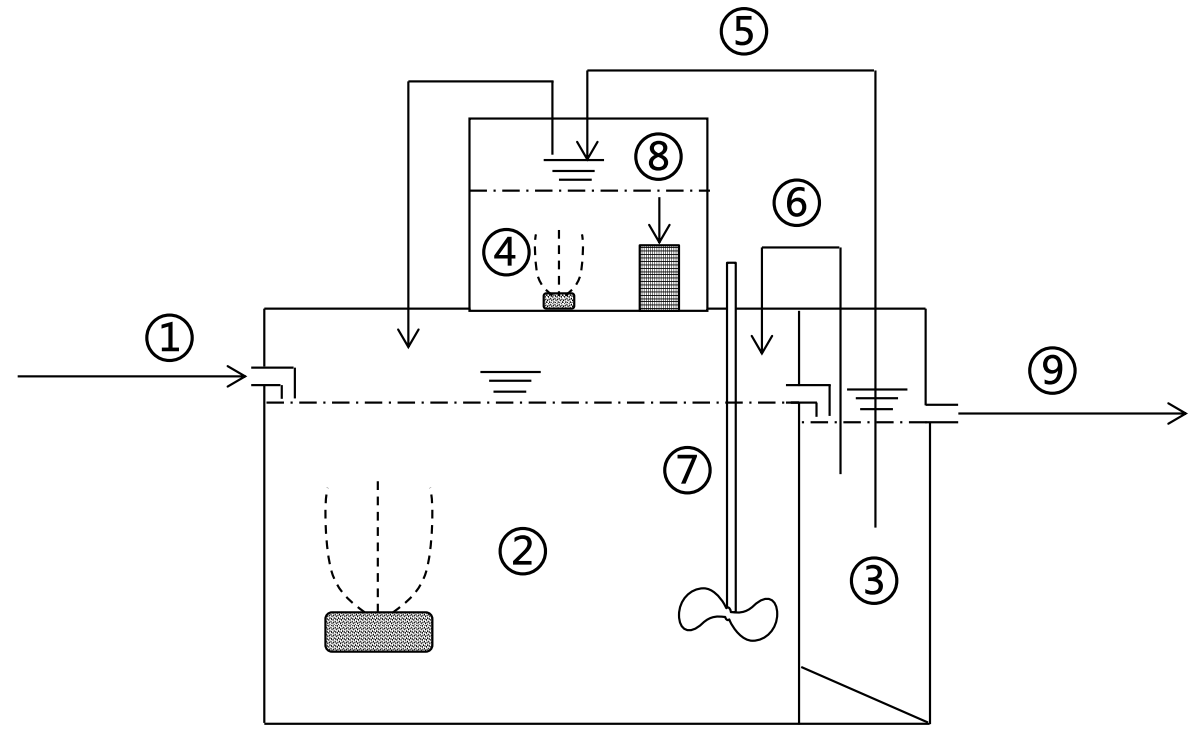

Figure 1. Laboratory scale wastewater treatment reactor. (1) influent, (2) aeration tank, (3) sedimentation tank, (4) reaction tank, (5) sludge reflux, (6) sludge return, (7) mechanical agitator, (8) pellet + pumice, (9) effluent

There were three reactors, which were controlled reactor, reactor one and reactor two. Six Pellet bacteria (about $363.72 \mathrm{~g}$ ) and $727.44 \mathrm{~g}$ pumice were added to the reaction tank of reactor one and six Pellet (about $363.72 \mathrm{~g}$ ), and $727.44 \mathrm{~g}$ pumice were added to the reaction tank of reactor two. The reaction tank of three reactors continued to be aerated. The reactor operation included two modes, which were long-term aeration and intermittent aeration. The intermittent aeration was divided into four stages, which were $1 \mathrm{~h} / 1 \mathrm{~h}$ (the first stage), $1 \mathrm{~h} 20 \mathrm{~min} / 1 \mathrm{~h}$ (the second stage), $1 \mathrm{~h} 20 \mathrm{~min} / 1 \mathrm{~h} 20 \mathrm{~min}$ (the third stage), $1 \mathrm{~h} / 1 \mathrm{~h}$ min (the fourth stage).

\section{Water quality analysis}

The researchers were analyzed the amount of $\mathrm{COD}, \mathrm{NH}_{3}-\mathrm{N}$ and $\mathrm{NO}_{3}-\mathrm{N}$ with APHA Standard Method (Gilcreas, 1998). The GB (GB 11901, 1989) was used to the analysis of SS. The pretreatment of TN and TP analysis was carried out by digestion with persulfate (Qualls, 1989) and the subsequent treatment followed the APHA Standard Method.

\section{$\mathrm{SiO}_{2}$ determination}

In the long-term aeration of 120 days, the concentration of $\mathrm{SiO}_{2}$ was measured from the aeration tank and the reaction tank. $\mathrm{SiO}_{2}$ was determined by citric acid extraction and silicon molybdenum blue colorimetric method (Bao, 2000). 


\section{Results and discussion}

\section{COD analysis}

Figure 2 shows that the influent COD concentration was from 2000 to $3000 \mathrm{mg} / \mathrm{L}$. For the control reactor, the effluent COD remained stable after running 113 days. The concentration range was stable from $189 \mathrm{mg} / \mathrm{L}$ to $237 \mathrm{mg} / \mathrm{L}$ and the average concentration was $208 \mathrm{mg} / \mathrm{L}$. Figure 3 shows that the average COD removal rate was from $91 \%$ to $94 \%$, and the average removal rate reached $93 \%$. For the reactor one, the effluent COD remains stable after running 99 days. The concentration is stable from 91 $\mathrm{mg} / \mathrm{L}$ to $117 \mathrm{mg} / \mathrm{L}$ and the average concentration is $101 \mathrm{mg} / \mathrm{L}$. The removal rate of COD is from $96 \%$ to $98 \%$ and the average removal rate reached $97 \%$. For the reactor two, the effluent COD remains stable after 106 days. and the concentration was stable from $91 \mathrm{mg} / \mathrm{L}$ to $128 \mathrm{mg} / \mathrm{L}$ and the average concentration was $110 \mathrm{mg} / \mathrm{L}$. The removal rate of COD was from $95 \%$ to $98 \%$ and the average removal rate reached $96 \%$. The effluent COD of the reactors one and two was less than $150 \mathrm{mg} / \mathrm{L}$. After the reactor operation was stable, the COD concentrations of the reactor one and two were lower than those of the control reactor and the reactor one was the lowest. It was shown that the removal effect for COD of reactor one was better than reactor two and both of them were better than the control reactor under the long-term aeration condition, which could be attributed with the creation of the bio-system which was similar to RBS in the reaction tanks of reactor one and two.

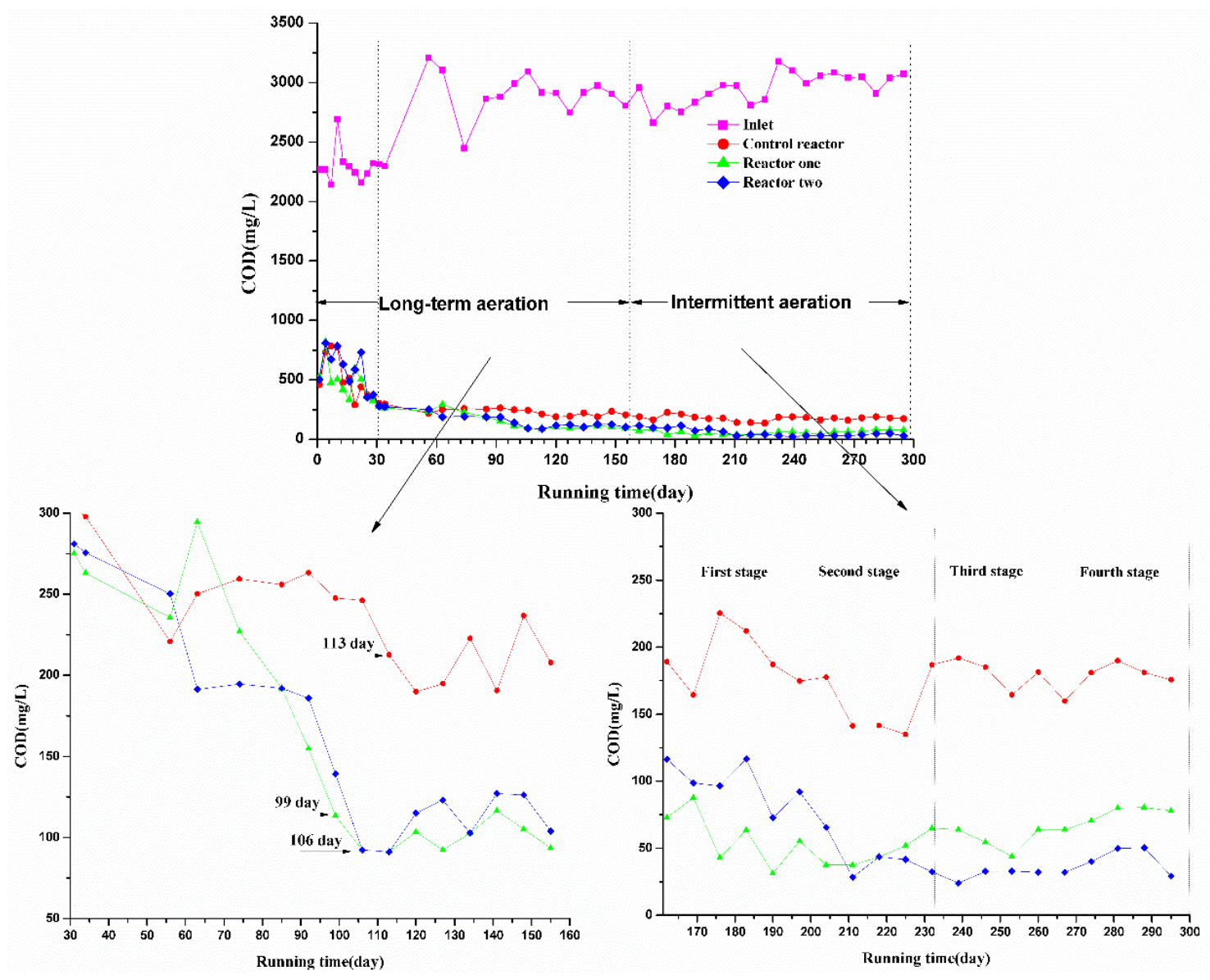

Figure 2. Changes of COD concentration in the influent and effluent 


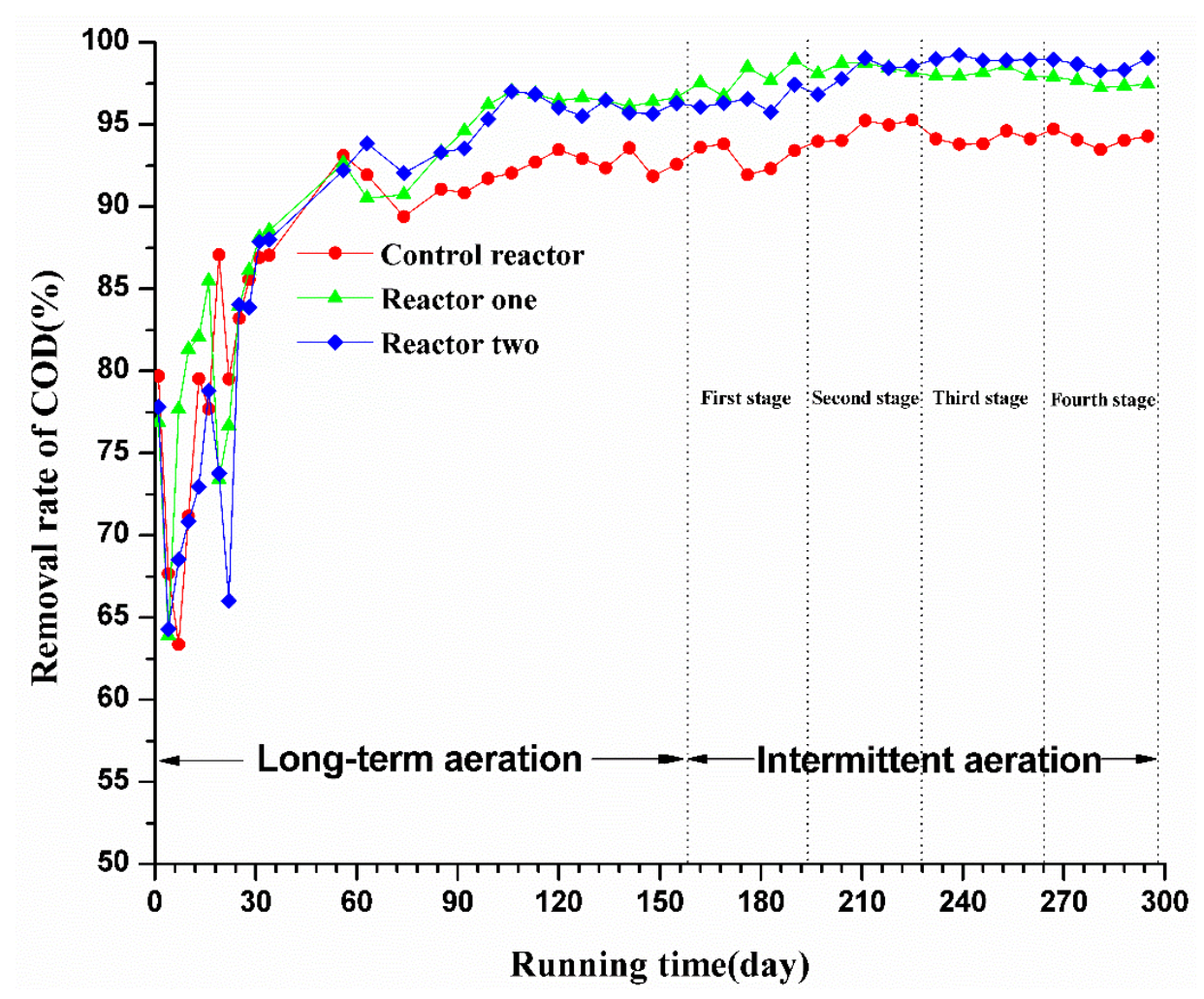

Figure 3. Changes of COD removal rate

During the four stages of intermittent aeration, the effluent COD concentration ranges as shown in Table 1. The average concentrations of four stages were 195.58 $\mathrm{mg} / \mathrm{L}, 154.05 \mathrm{mg} / \mathrm{L}, 181.91 \mathrm{mg} / \mathrm{L}, 177.57 \mathrm{mg} / \mathrm{L}$ in control reactor. The average concentrations of four stages were $59.62 \mathrm{mg} / \mathrm{L}, 43.47 \mathrm{mg} / \mathrm{L}, 58.25 \mathrm{mg} / \mathrm{L}, 74.60 \mathrm{mg} / \mathrm{L} \mathrm{in}$ reactor one. The average concentrations of four stages were $100.18 \mathrm{mg} / \mathrm{L}, 47.00 \mathrm{mg} / \mathrm{L}$, $30.80 \mathrm{mg} / \mathrm{L}, 40.37 \mathrm{mg} / \mathrm{L}$ in reactor two. Therefore, the lowest effluent COD concentration of control reactor appeared in the second stage. The removal rate of COD was from $92 \%$ to $96 \%$ and the average removal rate was $95 \%$. The lowest effluent COD concentration of reactor one appeared in the second stage. The removal rate of COD was from $98 \%$ to $99 \%$ and the average removal rate was $98 \%$. The lowest effluent COD concentration of reactor two appeared in the third stage. The removal rate of COD was from $98 \%$ to $100 \%$ and the average removal rate was $99 \%$. Therefore, for the removal of $\mathrm{COD}$, the most suitable aeration conditions for control reactor, reactor one, reactor two were $1 \mathrm{~h} 20 \mathrm{~min} / 1 \mathrm{~h}, 1 \mathrm{~h} 20 \mathrm{~min} / 1 \mathrm{~h}, 1 \mathrm{~h} 20 \mathrm{~min} / 1 \mathrm{~h} 20 \mathrm{~min}$. During the four stages of intermittent aeration, the effluent COD of reactors one and two was less than 150 $\mathrm{mg} / \mathrm{L}$.

Table 1. Effluent COD concentration ranges

\begin{tabular}{c|c|c|c}
\hline Stage & Control & Reactor one & Reactor two \\
\hline 1 & $164.38 \sim 225.50 \mathrm{mg} / \mathrm{L}$ & $31.17 \sim 87.67 \mathrm{mg} / \mathrm{L}$ & $72.73 \sim 116.56 \mathrm{mg} / \mathrm{L}$ \\
2 & $135.06 \sim 177.78 \mathrm{mg} / \mathrm{L}$ & $37.43 \sim 55.17 \mathrm{mg} / \mathrm{L}$ & $28.24 \sim 91.95 \mathrm{mg} / \mathrm{L}$ \\
3 & $164.38 \sim 192.00 \mathrm{mg} / \mathrm{L}$ & $43.84 \sim 64.97 \mathrm{mg} / \mathrm{L}$ & $24.00 \sim 32.88 \mathrm{mg} / \mathrm{L}$ \\
4 & $160.00 \sim 190.00 \mathrm{mg} / \mathrm{L}$ & $64.00 \sim 80.50 \mathrm{mg} / \mathrm{L}$ & $29.27 \sim 50.31 \mathrm{mg} / \mathrm{L}$ \\
\hline
\end{tabular}


Figure 4 shows that the COD concentrations in the aeration tank were stable after a long period of aeration of three reactors. The concentration of COD in the aeration tank of control reactor was reduced from $2000 \sim 3000 \mathrm{mg} / \mathrm{L}$ to $1000 \mathrm{mg} / \mathrm{L}$ while that of reactor one and reactor two was reduced to $800 \mathrm{mg} / \mathrm{L}$. After the intermittent aeration mode was converted to intermittent aeration, the COD concentrations in the aeration tank reduced. In the third stage of intermittent aeration, the COD concentrations in the aeration tank of three reactors were minimum and those of control reactor, reactor one, reactor two were $493.15 \mathrm{mg} / \mathrm{L}, 482.19 \mathrm{mg} / \mathrm{L}, 405.48 \mathrm{mg} / \mathrm{L}$. It was indicated that the aeration tank played an important role in the removal of COD in the long-term aeration stage and the intermittent aeration stage. Since the operating modes of three reactors were changed from long-term aeration to intermittent aeration, the COD removal efficiency has been increased.

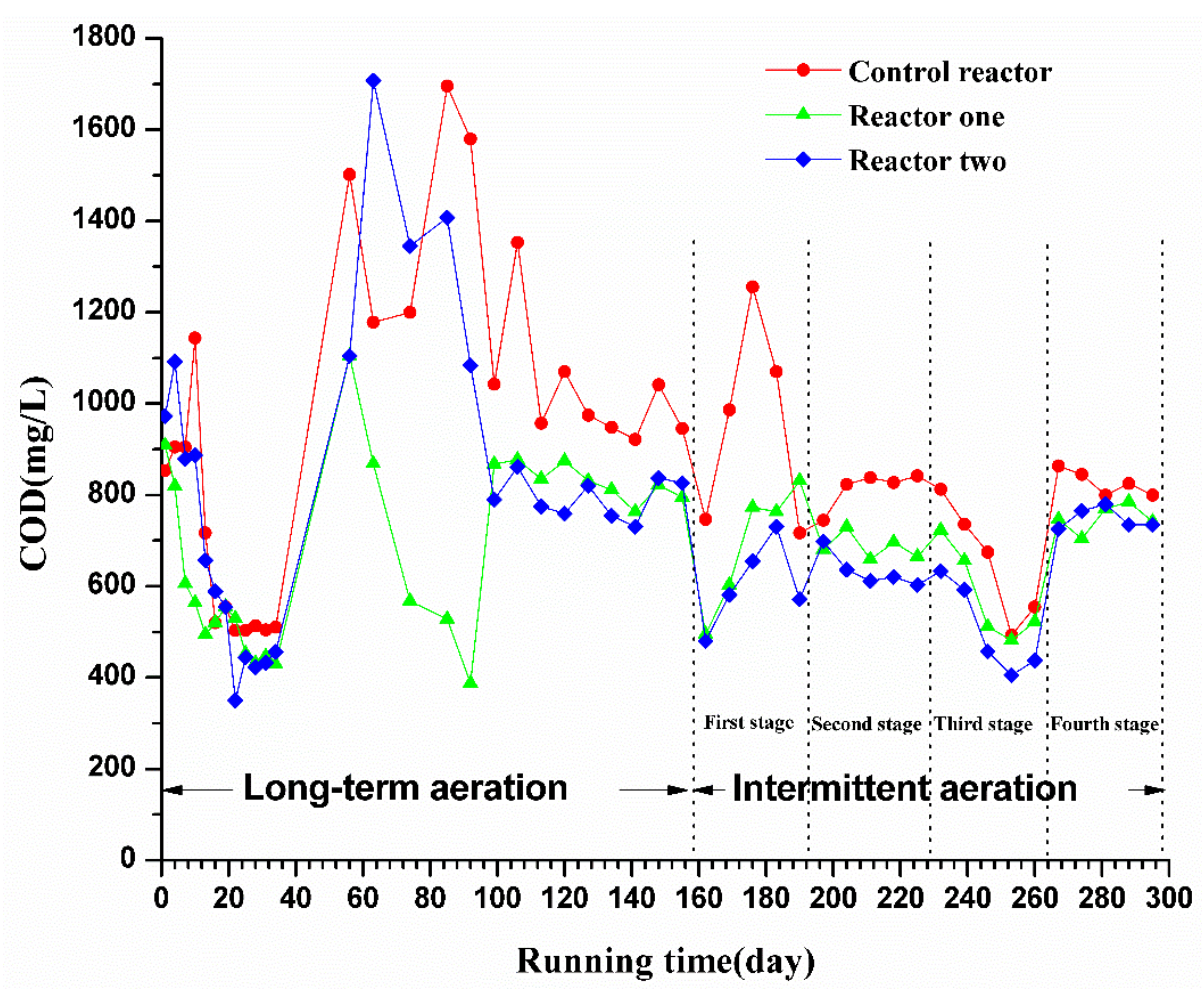

Figure 4. Changes of COD concentration in the aeration tank

\section{$\mathrm{NH}_{3}-\mathrm{N}$ analysis}

Figure 5 shows that the influent $\mathrm{NH}_{3}-\mathrm{N}$ concentration was from 35 to $70 \mathrm{mg} / \mathrm{L}$. For the control reactor, the effluent $\mathrm{NH}_{3}-\mathrm{N}$ remained stable after running 120 days. The concentration was stable from $26 \mathrm{mg} / \mathrm{L}$ to $32 \mathrm{mg} / \mathrm{L}$ and the average concentration was $30 \mathrm{mg} / \mathrm{L}$. Figure 6 shows that the average removal rate of $\mathrm{NH}_{3}-\mathrm{N}$ was from $10 \%$ to $24 \%$ and the average removal rate reached $16 \%$. For the reactor one, the effluent $\mathrm{NH}_{3}-\mathrm{N}$ remained stable after running 120 days. The concentration was stable from $22 \mathrm{mg} / \mathrm{L}$ to $27 \mathrm{mg} / \mathrm{L}$ and the average concentration was $24 \mathrm{mg} / \mathrm{L}$. The removal rate of $\mathrm{NH}_{3}-\mathrm{N}$ was from $25 \%$ to $40 \%$ and the average removal rate reached $33 \%$. For the reactor two, the effluent $\mathrm{NH}_{3}-\mathrm{N}$ remains stable after 120 days. The concentration was stable from 19 $\mathrm{mg} / \mathrm{L}$ to $26 \mathrm{mg} / \mathrm{L}$ and the average concentration was $22 \mathrm{mg} / \mathrm{L}$. The removal rate of $\mathrm{NH}_{3^{-}}$ 
$\mathrm{N}$ was from $29 \%$ to $46 \%$ and the average removal rate reached $38 \%$. The effluent $\mathrm{NH}_{3}-$ $\mathrm{N}$ of the reactor one and two were less than $25 \mathrm{mg} / \mathrm{L}$. When the reactor operation was stable, the $\mathrm{NH}_{3}-\mathrm{N}$ concentrations of the reactor one and two were lower than those of the control reactor and the reactor two was the lowest. It was shown that the removal effect for $\mathrm{NH}_{3}-\mathrm{N}$ of reactor two was better than that of reactor one and both of them were better than that of the control reactor under the long-term aeration condition, which could be attributed to the creation of the bio-system which was similar to RBS in the reaction tanks of reactor one and two.

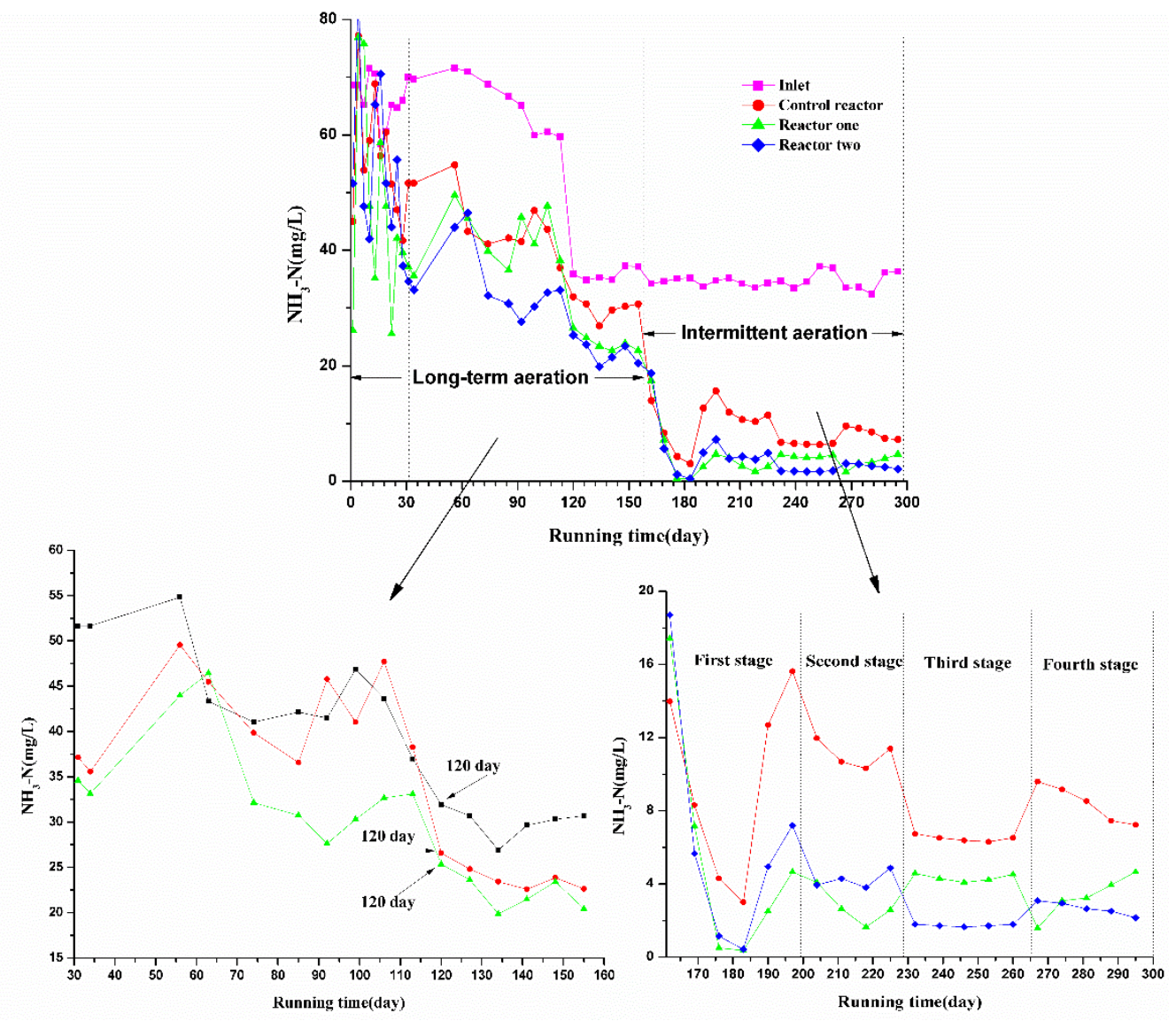

Figure 5. Changes of $\mathrm{NH}_{3}-\mathrm{N}$ concentration in the influent and effluent

During the four stages of intermittent aeration, the effluent $\mathrm{NH}_{3}-\mathrm{N}$ concentration ranges as shown in Table 2. The average concentrations of four stages were $8.46 \mathrm{mg} / \mathrm{L}$, $12.00 \mathrm{mg} / \mathrm{L}, 6.49 \mathrm{mg} / \mathrm{L}, 8.4 \mathrm{mg} / \mathrm{L}$ in control reactor. The average concentrations of four stages were $5.59 \mathrm{mg} / \mathrm{L}, 3.13 \mathrm{mg} / \mathrm{L}, 4.34 \mathrm{mg} / \mathrm{L}, 3.30 \mathrm{mg} / \mathrm{L}$ in reactor one. The average concentration of four stages were $6.18 \mathrm{mg} / \mathrm{L}, 4.82 \mathrm{mg} / \mathrm{L}, 1.73 \mathrm{mg} / \mathrm{L}, 2.67 \mathrm{mg} / \mathrm{L}$ in reactor two. Therefore, the lowest effluent $\mathrm{NH}_{3}-\mathrm{N}$ concentration of control reactor appeared in the third stage. The removal rate of $\mathrm{NH}_{3}-\mathrm{N}$ was from $71 \%$ to $81 \%$ and the average removal rate was $75 \%$. The lowest effluent $\mathrm{NH}_{3}-\mathrm{N}$ concentration of reactor one appeared in the second stage. The removal rate of $\mathrm{NH}_{3}-\mathrm{N}$ was from $82 \%$ to $96 \%$ and the average removal rate was $90 \%$. The lowest effluent $\mathrm{NH}_{3}-\mathrm{N}$ concentration of reactor two appeared in the third stage. The removal rate of $\mathrm{NH}_{3}-\mathrm{N}$ was from $90 \%$ to $95 \%$ and the average removal rate was $92 \%$. Therefore, for the removal of $\mathrm{NH}_{3}-\mathrm{N}$, the most suitable 
aeration conditions for control reactor, reactor one, reactor two were $1 \mathrm{~h} 20 \mathrm{~min} / 1 \mathrm{~h} 20$ $\mathrm{min}, 1 \mathrm{~h} 20 \mathrm{~min} / 1 \mathrm{~h}, 1 \mathrm{~h} 20 \mathrm{~min} / 1 \mathrm{~h} 20 \mathrm{~min}$. During the four stages of intermittent aeration, the effluent $\mathrm{NH}_{3}-\mathrm{N}$ of reactor one and two was less than $25 \mathrm{mg} / \mathrm{L}$.

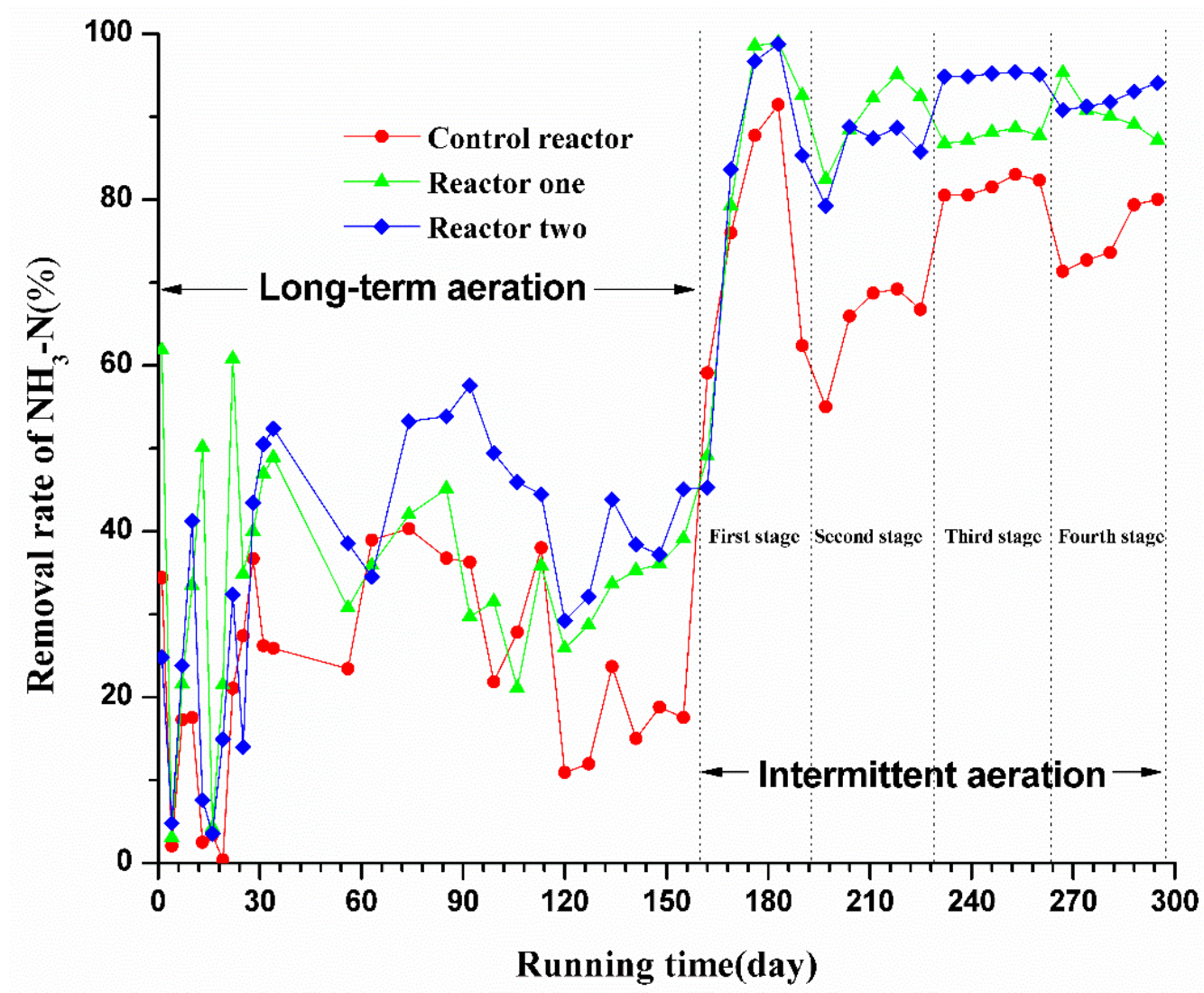

Figure 6. Changes of $\mathrm{NH}_{3}-\mathrm{N}$ removal rate

Table 2. Effluent $\mathrm{NH}_{3}-\mathrm{N}$ concentration ranges

\begin{tabular}{c|c|c|c}
\hline Stage & Control & Reactor one & Reactor two \\
\hline 1 & $3.01 \sim 13.98 \mathrm{mg} / \mathrm{L}$ & $0.36 \sim 17.42 \mathrm{mg} / \mathrm{L}$ & $0.43 \sim 18.71 \mathrm{mg} / \mathrm{L}$ \\
2 & $10.32 \sim 15.63 \mathrm{mg} / \mathrm{L}$ & $1.65 \sim 6.09 \mathrm{mg} / \mathrm{L}$ & $3.80 \sim 7.20 \mathrm{mg} / \mathrm{L}$ \\
3 & $6.31 \sim 6.74 \mathrm{mg} / \mathrm{L}$ & $4.09 \sim 4.58 \mathrm{mg} / \mathrm{L}$ & $1.65 \sim 1.79 \mathrm{mg} / \mathrm{L}$ \\
4 & $7.24 \sim 9.60 \mathrm{mg} / \mathrm{L}$ & $1.58 \sim 4.66 \mathrm{mg} / \mathrm{L}$ & $2.15 \sim 3.08 \mathrm{mg} / \mathrm{L}$ \\
\hline
\end{tabular}

Figure 7 shows that the $\mathrm{NH}_{3}-\mathrm{N}$ concentrations in the aeration tank were stable after a long period of aeration of three reactors. The concentration of $\mathrm{NH}_{3}-\mathrm{N}$ in the aeration tank of control reactor was reduced from $30 \sim 70 \mathrm{mg} / \mathrm{L}$ to $28 \mathrm{mg} / \mathrm{L}$ while that of reactor one and reactor two was reduced to $22 \mathrm{mg} / \mathrm{L}$ and $21 \mathrm{mg} / \mathrm{L}$. After the intermittent aeration mode was converted to intermittent aeration, the $\mathrm{NH}_{3}-\mathrm{N}$ concentrations in the aeration tank of three reactors were reduced. In the third stage of intermittent aeration, the $\mathrm{NH}_{3}-\mathrm{N}$ concentrations in the aeration tank of three reactors were minimum and that of control reactor, reactor one, reactor two were $2.29 \mathrm{mg} / \mathrm{L}, 0.22 \mathrm{mg} / \mathrm{L}, 0.57 \mathrm{mg} / \mathrm{L}$. It was indicated that the aeration tank played an important role in the removal of $\mathrm{NH}_{3}-\mathrm{N}$ in 
the long-term aeration stage and the intermittent aeration stage. Since the operating modes of three reactors were changed from long-term aeration to intermittent aeration, the COD removal efficiency increased.

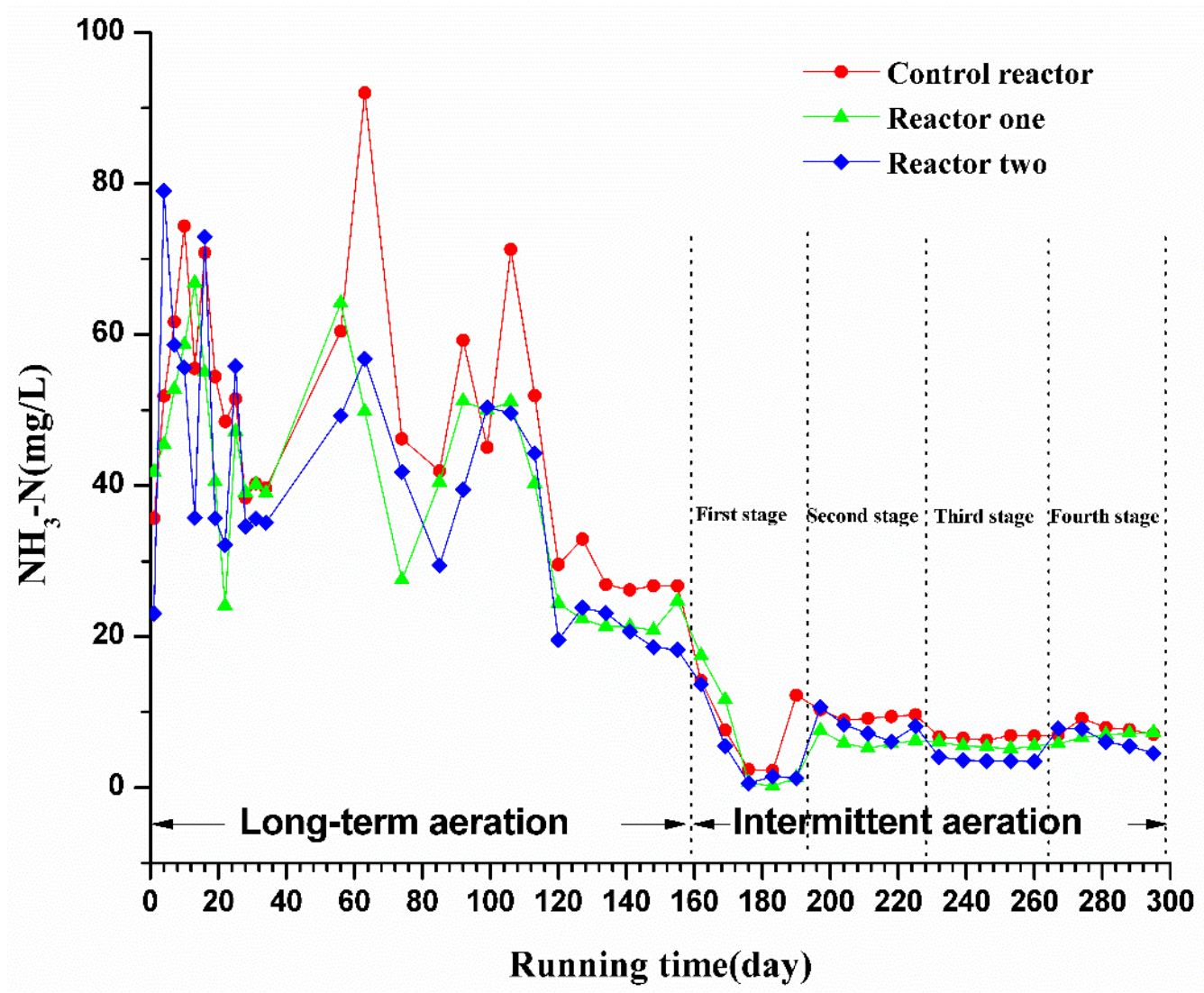

Figure 7. Changes of $\mathrm{NH}_{3}-\mathrm{N}$ concentration in the aeration tank

\section{$\mathrm{NO}_{3}-\mathrm{N}$ analysis}

Figure 8 shows that the influent $\mathrm{NO}_{3}-\mathrm{N}$ concentration was from 10 to $15 \mathrm{mg} / \mathrm{L}$. For the control reactor, the effluent $\mathrm{NO}_{3}-\mathrm{N}$ remained stable after running 120 days. The concentration was stable from $8 \mathrm{mg} / \mathrm{L}$ to $13 \mathrm{mg} / \mathrm{L}$ and the average concentration was 11 $\mathrm{mg} / \mathrm{L}$. Figure 9 shows that the average removal rate of $\mathrm{NO}_{3}-\mathrm{N}$ was lower than $24 \%$ and the average removal rate reached $13 \%$. For the reactor one, the effluent $\mathrm{NO}_{3}-\mathrm{N}$ remains stable after running 106 days. The concentration was stable from $7 \mathrm{mg} / \mathrm{L}$ to $11 \mathrm{mg} / \mathrm{L}$ and the average concentration reached $8 \mathrm{mg} / \mathrm{L}$. The removal rate of $\mathrm{NO}_{3}-\mathrm{N}$ was from $10 \%$ to $41 \%$ and the average removal rate reached $30 \%$. For the reactor two, the effluent $\mathrm{NO}_{3}-\mathrm{N}$ remains stable after running 99 days, and the concentration was stable from 7 $\mathrm{mg} / \mathrm{L}$ to $9 \mathrm{mg} / \mathrm{L}$ and the average concentration was $8 \mathrm{mg} / \mathrm{L}$. The removal rate of $\mathrm{NO}_{3}-\mathrm{N}$ was from $7 \%$ to $40 \%$ and the average removal rate reached $30 \%$. When the reactor operation was stable, the $\mathrm{NO}_{3}-\mathrm{N}$ concentrations of the reactor one and two were lower than that of the control reactor. It was shown that the removal effect of reactor one and reactor two on $\mathrm{NO}_{3}-\mathrm{N}$ was better than the control reactor under the long-term aeration condition, which could be attributed to the creation of the bio-system which was similar to RBS in the reaction tanks of reactor one and two. 


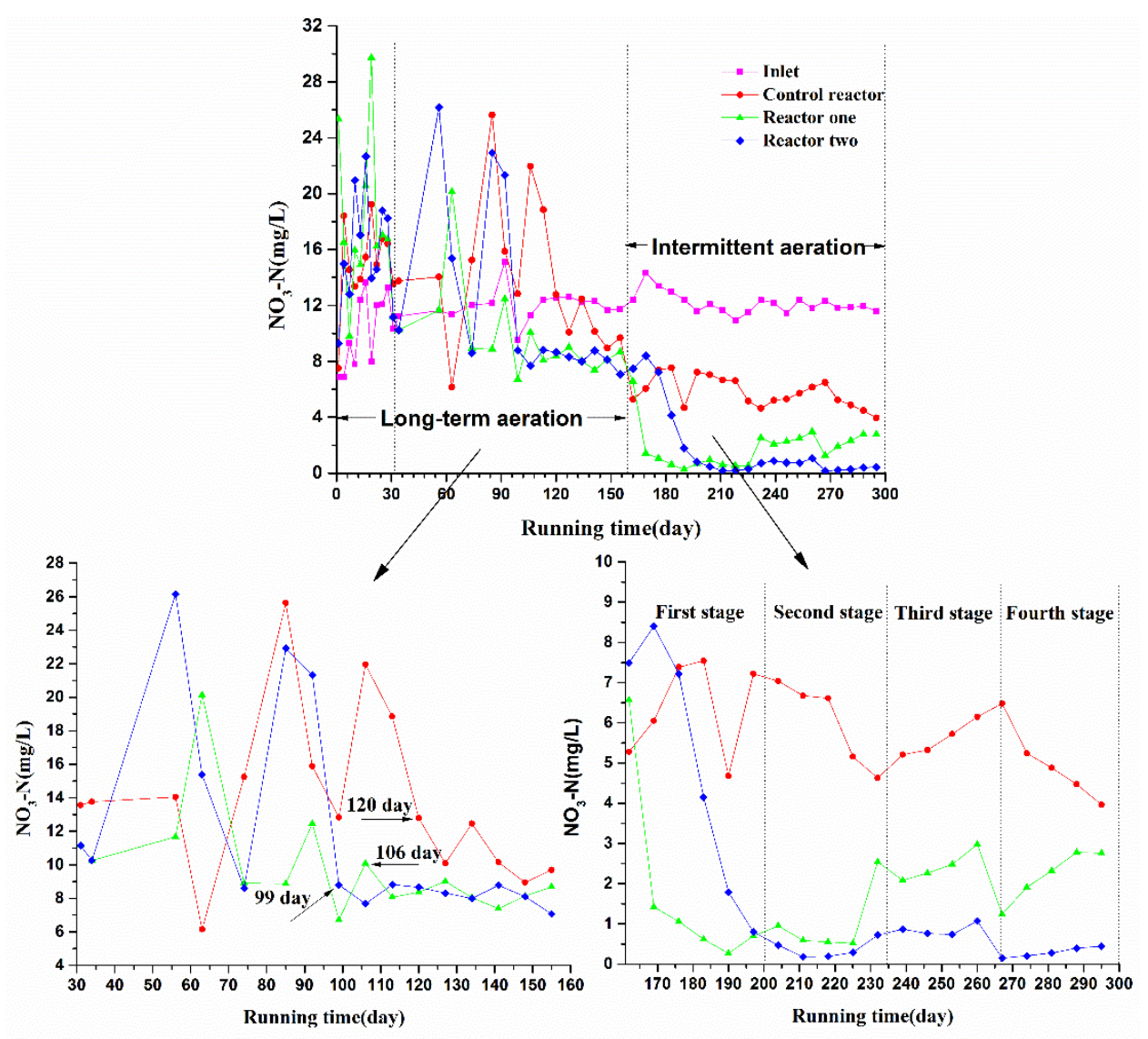

Figure 8. Changes of $\mathrm{NO}_{3}-\mathrm{N}$ concentration in the influent and effluent

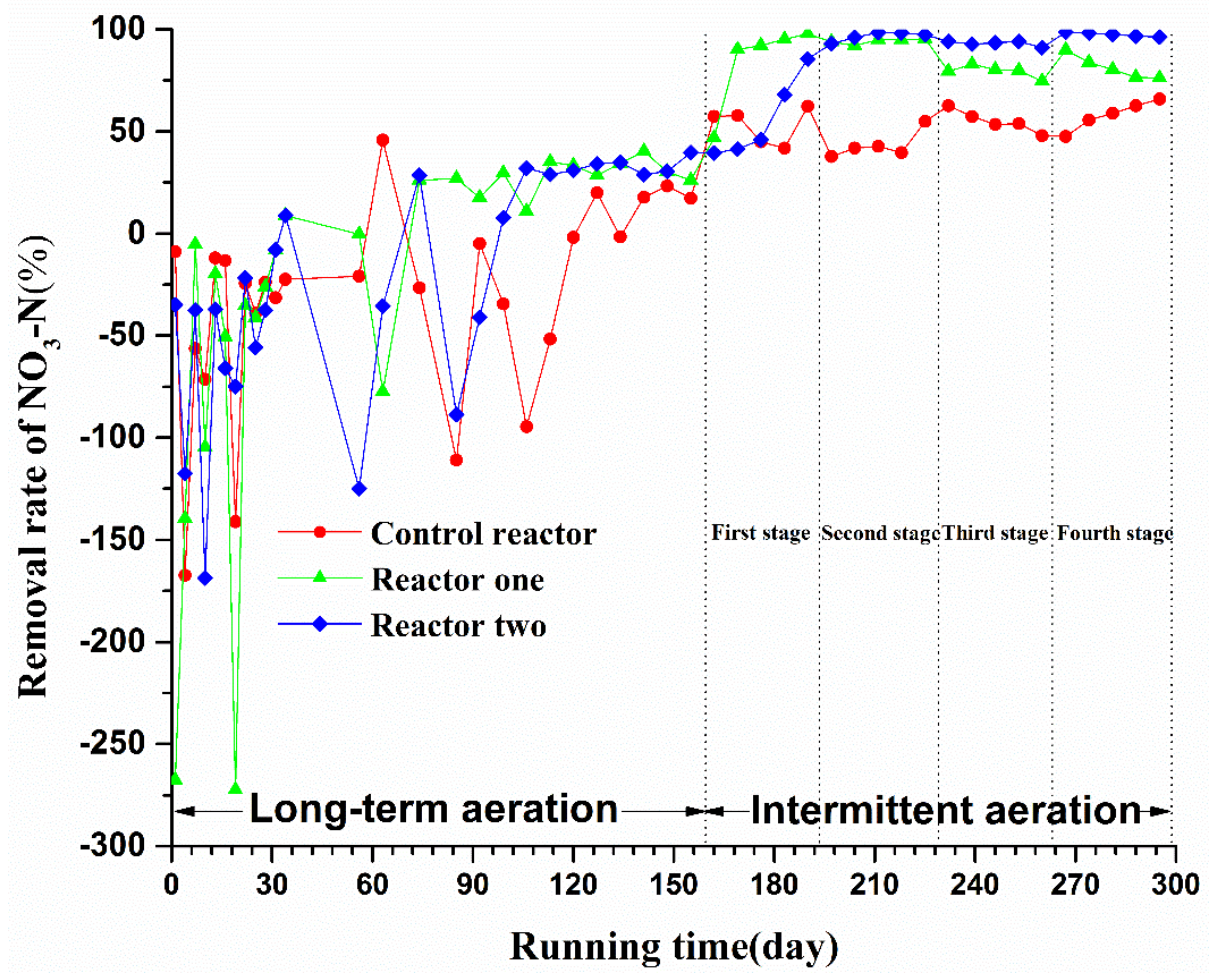

Figure 9. Changes of $\mathrm{NO}_{3}-\mathrm{N}$ removal rate 
During the four stages of intermittent aeration, the effluent $\mathrm{NO}_{3}-\mathrm{N}$ concentration ranges as shown in Table 3. The average concentrations of four stages were $6.19 \mathrm{mg} / \mathrm{L}$, $6.54 \mathrm{mg} / \mathrm{L}, 5.41 \mathrm{mg} / \mathrm{L}, 5.01 \mathrm{mg} / \mathrm{L}$ in control reactor. The average concentrations of four stages were $1.99 \mathrm{mg} / \mathrm{L}, 0.66 \mathrm{mg} / \mathrm{L}, 2.47 \mathrm{mg} / \mathrm{L}, 2.20 \mathrm{mg} / \mathrm{L}$ in reactor one. The average concentrations of four stages were $0.39 \mathrm{mg} / \mathrm{L}, 0.39 \mathrm{mg} / \mathrm{L}, 0.83 \mathrm{mg} / \mathrm{L}, 0.30 \mathrm{mg} / \mathrm{L}$ in reactor two. Evidently, among the effluent $\mathrm{NO}_{3}-\mathrm{N}$ concentrations of the four stages, the lowest was one of the last stage. The removal rate of $\mathrm{NO}_{3}-\mathrm{N}$ was from $47 \%$ to $63 \%$, and the average removal rate was 55\%. The lowest effluent $\mathrm{NO}_{3}-\mathrm{N}$ concentration of reactor one was the one of the second stage. The removal rate of $\mathrm{NO}_{3}-\mathrm{N}$ was from $92 \%$ to $96 \%$, and the average removal rate was $94 \%$. The lowest effluent $\mathrm{NO}_{3}-\mathrm{N}$ concentration of reactor two was the one of the fourth stage. The removal rate of $\mathrm{NO}_{3}-\mathrm{N}$ was from $90 \%$ to $95 \%$, and the average removal rate was $93 \%$. Obviously, for the removal of $\mathrm{NO}_{3}-\mathrm{N}$, the most suitable aeration conditions for control reactor, reactor one, reactor two were 1 h/1 h $20 \mathrm{~min}, 1 \mathrm{~h} 20 \mathrm{~min} / 1 \mathrm{~h}, 1 \mathrm{~h} / 1 \mathrm{~h} 20 \mathrm{~min}$.

Figure 10 shows that the $\mathrm{NO}_{3}-\mathrm{N}$ concentrations of three reactors in the aeration tank were stable after a long period of aeration while the concentration of $\mathrm{NO}_{3}-\mathrm{N}$ was higher than the influent. After the intermittent aeration mode was converted to intermittent aeration, the $\mathrm{NO}_{3}-\mathrm{N}$ concentrations in aeration tank has reduced. In the fourth stage of intermittent aeration, the $\mathrm{NO}_{3}-\mathrm{N}$ concentrations in the aeration tank of the three reactors were minimum and those of control reactor, reactor one, reactor two were $7.19 \mathrm{mg} / \mathrm{L}$, $0.45 \mathrm{mg} / \mathrm{L}, 0.34 \mathrm{mg} / \mathrm{L}$. It was indicated that the aeration tank played an important role in the removal of $\mathrm{NO}_{3}-\mathrm{N}$ in the long-term aeration stage and the intermittent aeration stage. Since the operating modes of three reactors were changed from long-term aeration to intermittent aeration, the COD removal efficiency increased.

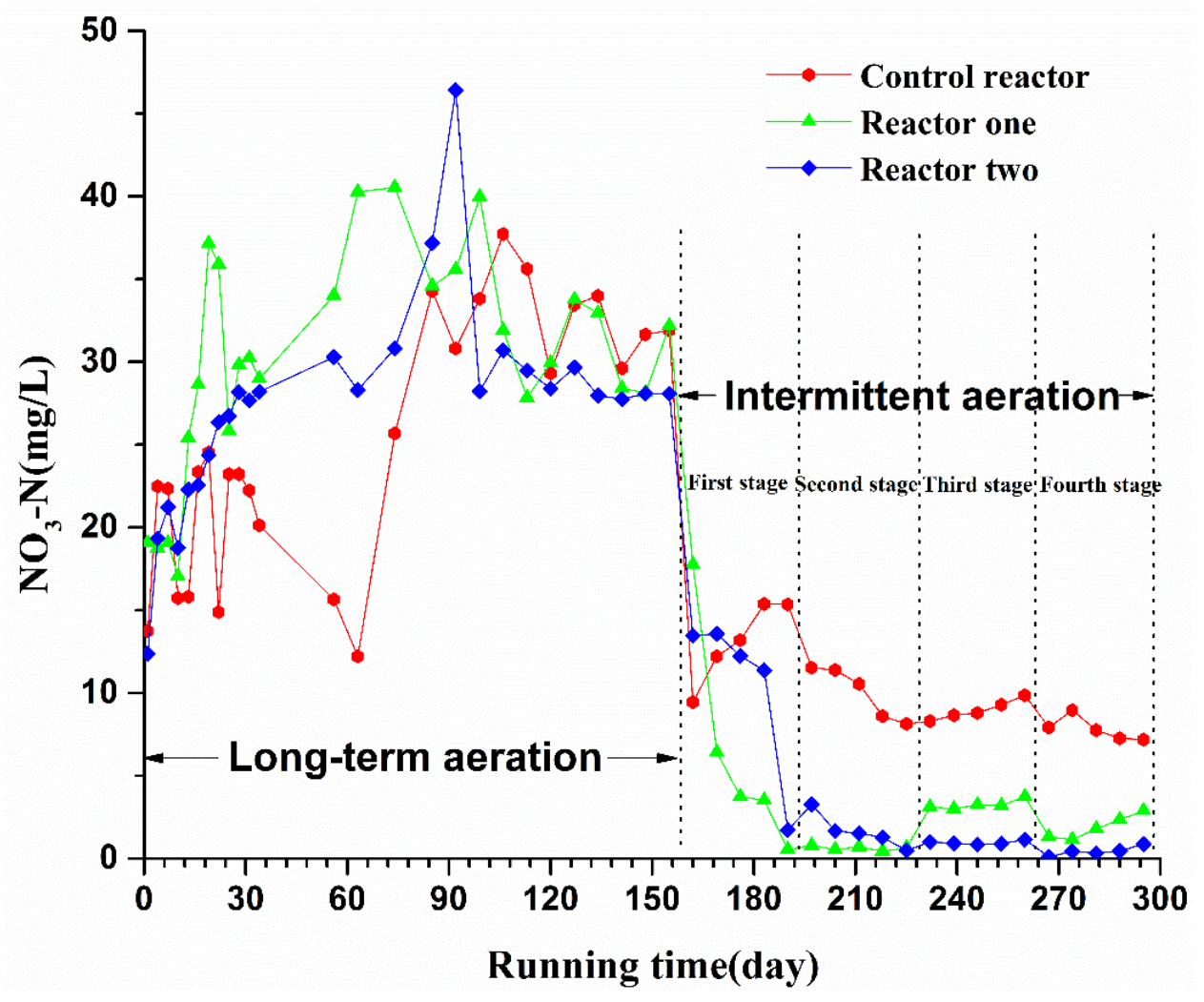

Figure 10. Changes of $\mathrm{NO}_{3}-\mathrm{N}$ concentration in the aeration tank 
Table 3. effluent $\mathrm{NO}_{3}-\mathrm{N}$ concentration ranges

\begin{tabular}{c|c|c|c}
\hline Stage & Control & Reactor one & Reactor two \\
\hline 1 & $5.28 \sim 7.54 \mathrm{mg} / \mathrm{L}$ & $0.27 \sim 6.57 \mathrm{mg} / \mathrm{L}$ & $1.79 \sim 8.40 \mathrm{mg} / \mathrm{L}$ \\
2 & $5.16 \sim 7.22 \mathrm{mg} / \mathrm{L}$ & $0.52 \sim 0.95 \mathrm{mg} / \mathrm{L}$ & $0.18 \sim 0.80 \mathrm{mg} / \mathrm{L}$ \\
3 & $4.63 \sim 6.15 \mathrm{mg} / \mathrm{L}$ & $2.08 \sim 2.98 \mathrm{mg} / \mathrm{L}$ & $0.72 \sim 1.07 \mathrm{mg} / \mathrm{L}$ \\
4 & $3.96 \sim 6.48 \mathrm{mg} / \mathrm{L}$ & $1.24 \sim 2.78 \mathrm{mg} / \mathrm{L}$ & $0.15 \sim 0.44 \mathrm{mg} / \mathrm{L}$ \\
\hline
\end{tabular}

\section{TN analysis}

Figure 11 shows that the influent TN concentration was from 10 to $15 \mathrm{mg} / \mathrm{L}$. For the control reactor, the effluent $\mathrm{TN}$ remained stable after running 113 days. The concentration was stable from $60 \mathrm{mg} / \mathrm{L}$ to $64 \mathrm{mg} / \mathrm{L}$ and the average concentration was $62 \mathrm{mg} / \mathrm{L}$.

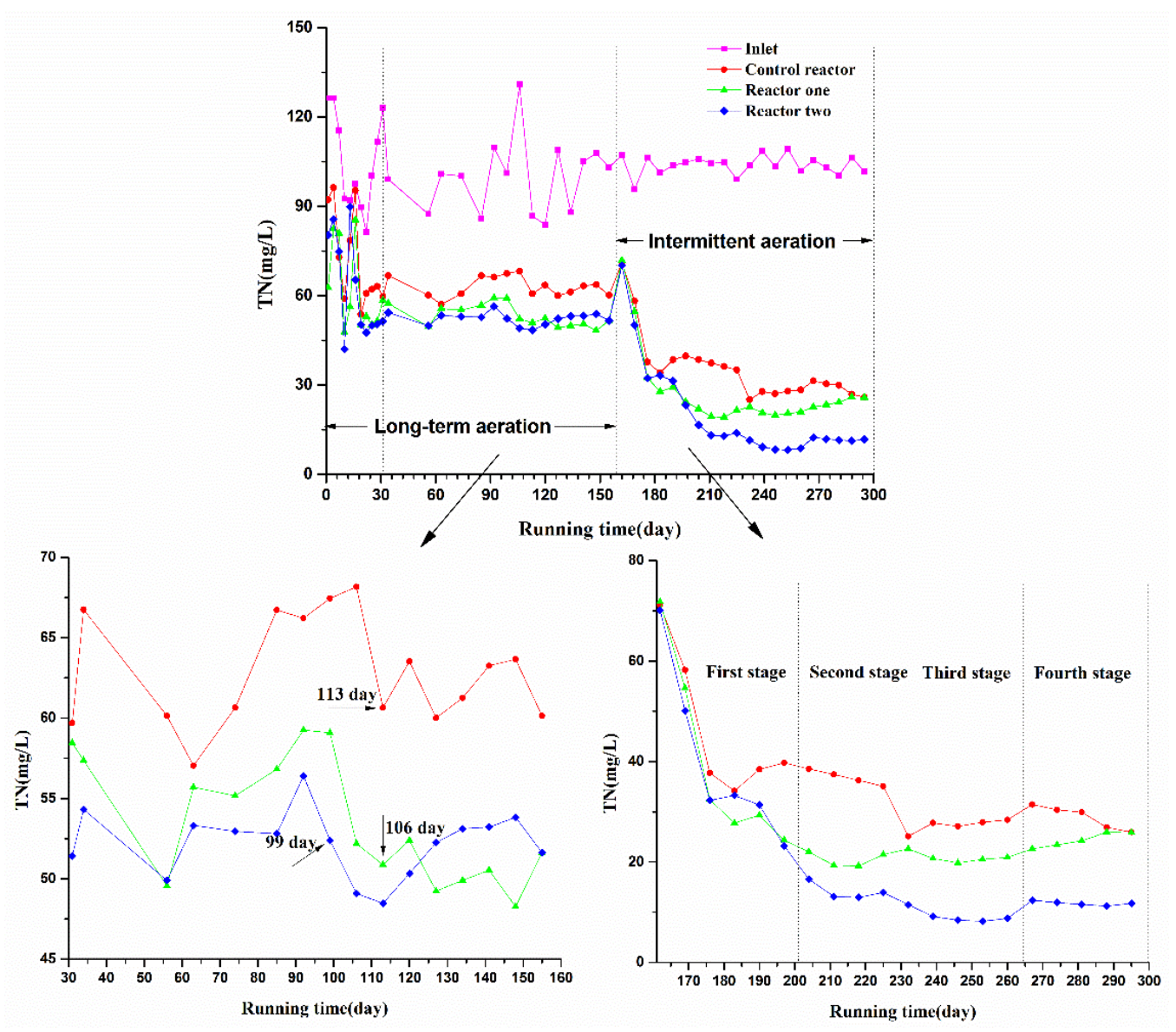

Figure 11. Changes of TN concentration in the influent and effluent

Figure 12 shows that the average removal rate of TN was from $39 \%$ to $54 \%$ and the average removal rate reached $43 \%$. For the reactor one, the effluent TN remained stable after running 106 days. The concentration was stable from $48 \mathrm{mg} / \mathrm{L}$ to $53 \mathrm{mg} / \mathrm{L}$ and the average concentration was $50 \mathrm{mg} / \mathrm{L}$. The removal rate of TN was from $49 \%$ to $62 \%$ and the average removal rate reached $54 \%$. For the reactor two, the effluent $\mathrm{TN}$ remains 
stable after running 99 days. The concentration was stable from $48 \mathrm{mg} / \mathrm{L}$ to $54 \mathrm{mg} / \mathrm{L}$ and the average concentration was $51 \mathrm{mg} / \mathrm{L}$. The removal rate of TN was from $48 \%$ to $64 \%$ and the average removal rate reached $54 \%$. When the reactor operation was stable, the TN concentrations of the reactor one and two were lower than those of the control reactor and the reactor one was the lowest. It was shown that the removal effect for TN of reactor one was better than reactor two and both of them were better than the control reactor under the long-term aeration condition, which could be attributed to the creation of the bio-system which was similar to RBS in the reaction tanks of reactor one and two.

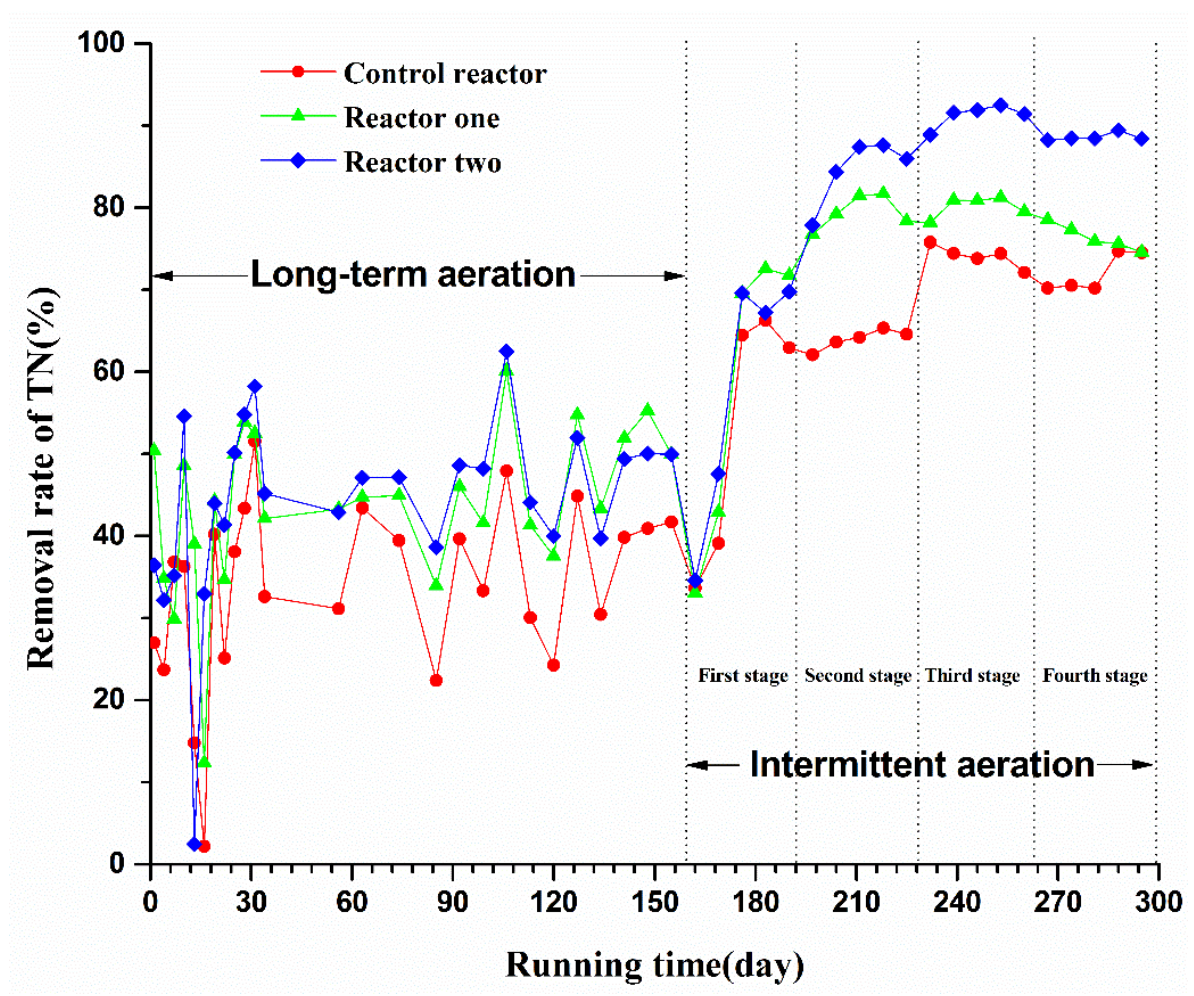

Figure 12. Changes of $T N$ removal rate

During the four stages of intermittent aeration, the effluent $\mathrm{TN}$ concentration ranges as shown in Table 4. The average concentrations of four stages were $47.94 \mathrm{mg} / \mathrm{L}, 37.39$ $\mathrm{mg} / \mathrm{L}, 27.25 \mathrm{mg} / \mathrm{L}, 28.90 \mathrm{mg} / \mathrm{L}$ in control reactor. The average concentrations of four stages were $43.16 \mathrm{mg} / \mathrm{L}, 20.90 \mathrm{mg} / \mathrm{L}, 21.26 \mathrm{mg} / \mathrm{L}, 24.39 \mathrm{mg} / \mathrm{L}$ in reactor one. The average concentration of four stages are $43.42 \mathrm{mg} / \mathrm{L}, 15.94 \mathrm{mg} / \mathrm{L}, 9.18 \mathrm{mg} / \mathrm{L}, 11.76$ $\mathrm{mg} / \mathrm{L}$ in reactor two. It can be observed that the lowest effluent TN concentration of control reactor was the one of the third stage. The removal rate of TN was from $70 \%$ to $75 \%$ and the average removal rate was $72 \%$. The lowest effluent $\mathrm{TN}$ concentration of reactor was the one of the second stage. The removal rate of TN was from $76 \%$ to $82 \%$ and the average removal rate was $80 \%$. The lowest effluent TN concentration of reactor two was the one of the fourth stage. The removal rate of TN was from $88 \%$ to $90 \%$ and the average removal rate was $89 \%$. Therefore, for the removal of $\mathrm{TN}$, the most suitable aeration conditions for control reactor, reactor one and reactor two were $1 \mathrm{~h} 20 \mathrm{~min} / 1 \mathrm{~h}$ $20 \mathrm{~min}, 1 \mathrm{~h} 20 \mathrm{~min} / 1 \mathrm{~h}, 1 \mathrm{~h} 20 \mathrm{~min} / 1 \mathrm{~h} 20 \mathrm{~min}$. 
Table 4. Effluent TN concentration ranges

\begin{tabular}{c|c|c|c}
\hline Stage & Control & Reactor one & Reactor two \\
\hline 1 & $34.14 \sim 74.16 \mathrm{mg} / \mathrm{L}$ & $27.78 \sim 71.78 \mathrm{mg} / \mathrm{L}$ & $31.35 \sim 70.13 \mathrm{mg} / \mathrm{L}$ \\
2 & $35.06 \sim 39.74 \mathrm{mg} / \mathrm{L}$ & $19.18 \sim 24.34 \mathrm{mg} / \mathrm{L}$ & $12.93 \sim 23.17 \mathrm{mg} / \mathrm{L}$ \\
3 & $25.09 \sim 28.39 \mathrm{mg} / \mathrm{L}$ & $19.80 \sim 22.62 \mathrm{mg} / \mathrm{L}$ & $8.18 \sim 11.48 \mathrm{mg} / \mathrm{L}$ \\
4 & $25.92 \sim 31.42 \mathrm{mg} / \mathrm{L}$ & $22.62 \sim 25.92 \mathrm{mg} / \mathrm{L}$ & $11.21 \sim 12.38 \mathrm{mg} / \mathrm{L}$ \\
\hline
\end{tabular}

Figure 13 shows that the TN concentrations of three reactors in the aeration tank were stable after a long period of aeration. The TN concentration of control reactor was higher than the influent concentration while that of reactor one and reactor two reduced to $97 \mathrm{mg} / \mathrm{L}$ and $95 \mathrm{mg} / \mathrm{L}$. After the intermittent aeration mode was converted to intermittent aeration, the TN concentrations in the aeration tank have reduced. In the first stage of intermittent aeration, the TN concentration in the aeration tank of control reactor was minimum and that of control reactor was $54.04 \mathrm{mg} / \mathrm{L}$. In the first stage of intermittent aeration, the TN concentration in the aeration tank of reactor one was minimum and that of reactor one was $45.38 \mathrm{mg} / \mathrm{L}$. In the third stage of intermittent aeration, the TN concentration in aeration tank of reactor two was minimum and that of reactor two was $34.1 \mathrm{mg} / \mathrm{L}$. It was indicated that the aeration tank played an important role in the removal of $\mathrm{TN}$ in the long-term aeration stage and the intermittent aeration stage. Since the operating modes of three reactors were changed from long-term aeration to intermittent aeration, the COD removal efficiency increased.

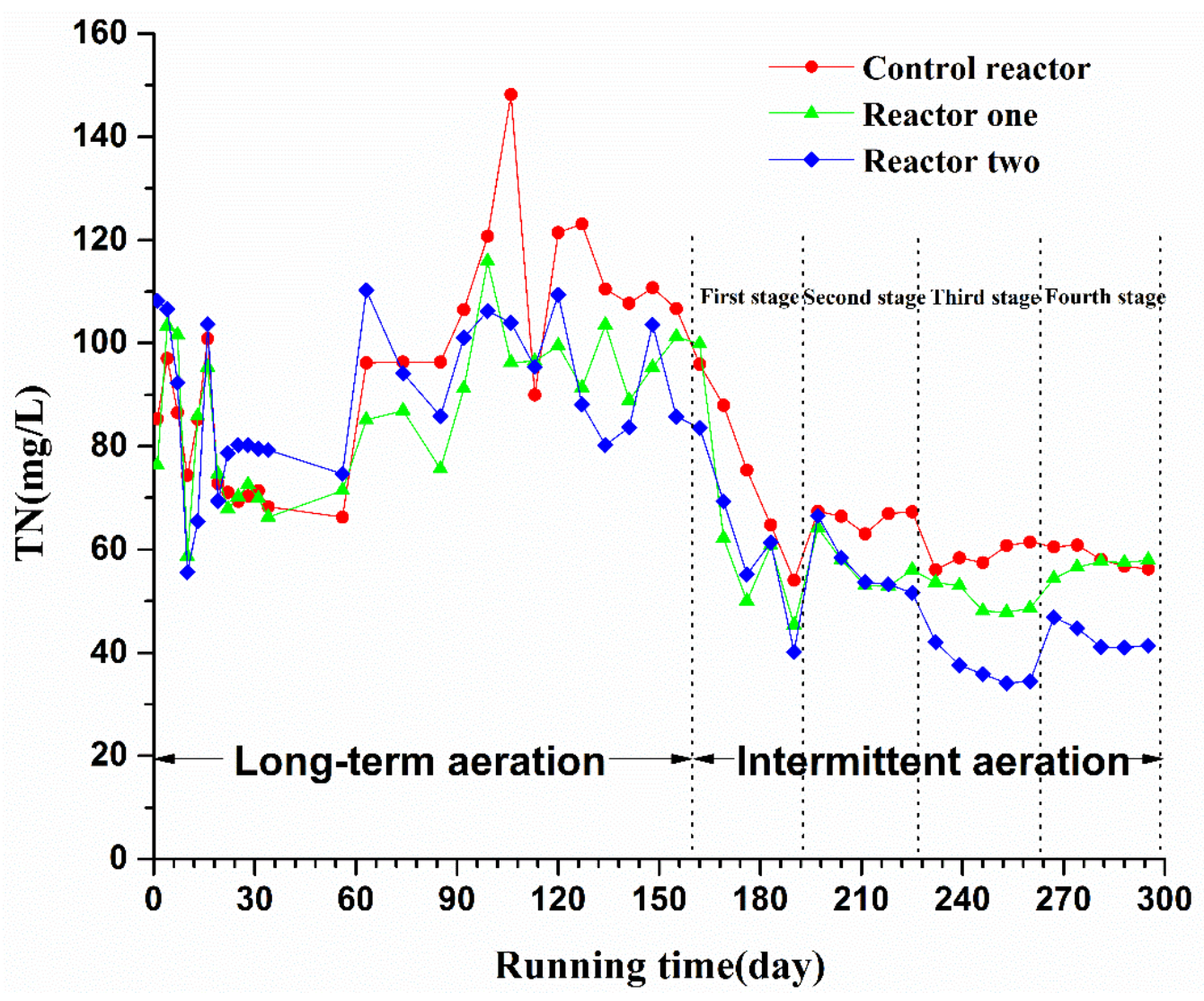

Figure 13. Changes of TN concentration in the aeration tank 


\section{TP analysis}

Figure 14 shows that the influent TP concentration was from 30 to $40 \mathrm{mg} / \mathrm{L}$. For the control reactor, the effluent $\mathrm{TP}$ remained stable after running 120 days. The concentration was stable from $25 \mathrm{mg} / \mathrm{L}$ to $29 \mathrm{mg} / \mathrm{L}$ and the average concentration was $27 \mathrm{mg} / \mathrm{L}$. Figure 15 shows that the average removal rate of TP was from $8 \%$ to $18 \%$ and the average removal rate reached $12 \%$. For the reactor one, the effluent TP remained stable after running 113 days. The concentration was stable from $20 \mathrm{mg} / \mathrm{L}$ to $24 \mathrm{mg} / \mathrm{L}$ and the average concentration was $22 \mathrm{mg} / \mathrm{L}$. The removal rate of TP was from $22 \%$ to $33 \%$ and the average removal rate reached $28 \%$. For the reactor two, the effluent TP remains stable after running 113 days. The concentration was stable from $20 \mathrm{mg} / \mathrm{L}$ to $24 \mathrm{mg} / \mathrm{L}$ and the average concentration was $21 \mathrm{mg} / \mathrm{L}$. The removal rate of TP was from $26 \%$ to $34 \%$ and the average removal rate reached $30 \%$. After the reactor operation was stable, the TP concentrations of the reactor one and two were lower than those of the control reactor, and the reactor two was the lowest. It was shown that the removal effect on TP of reactor two was better than reactor one and both of them were better than the control reactor under the long-term aeration condition, which could be attributed to the creation of the bio-system which was similar to RBS in the reaction tanks of reactor one and two.

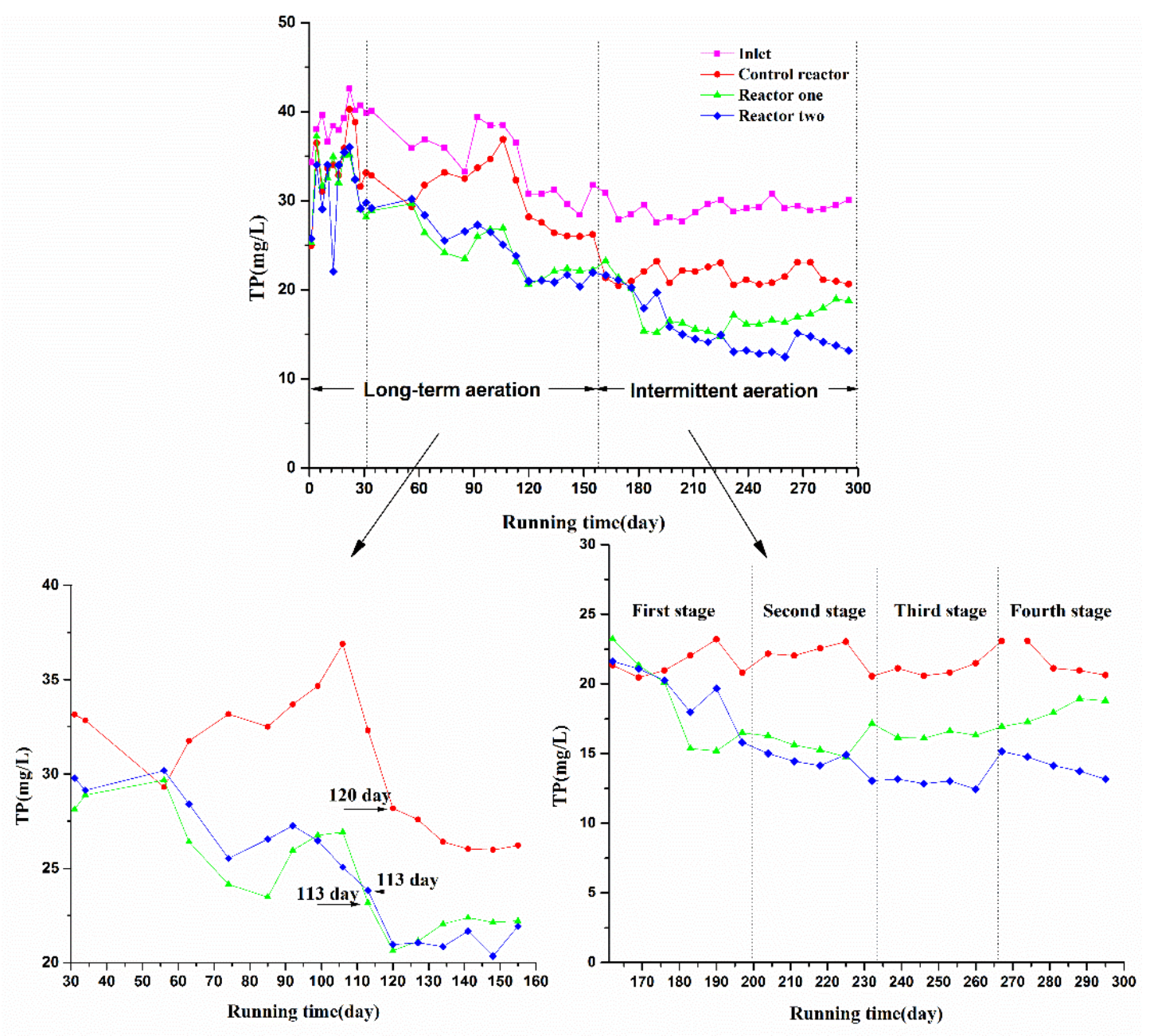

Figure 14. Changes of TP concentration in the influent and effluent 


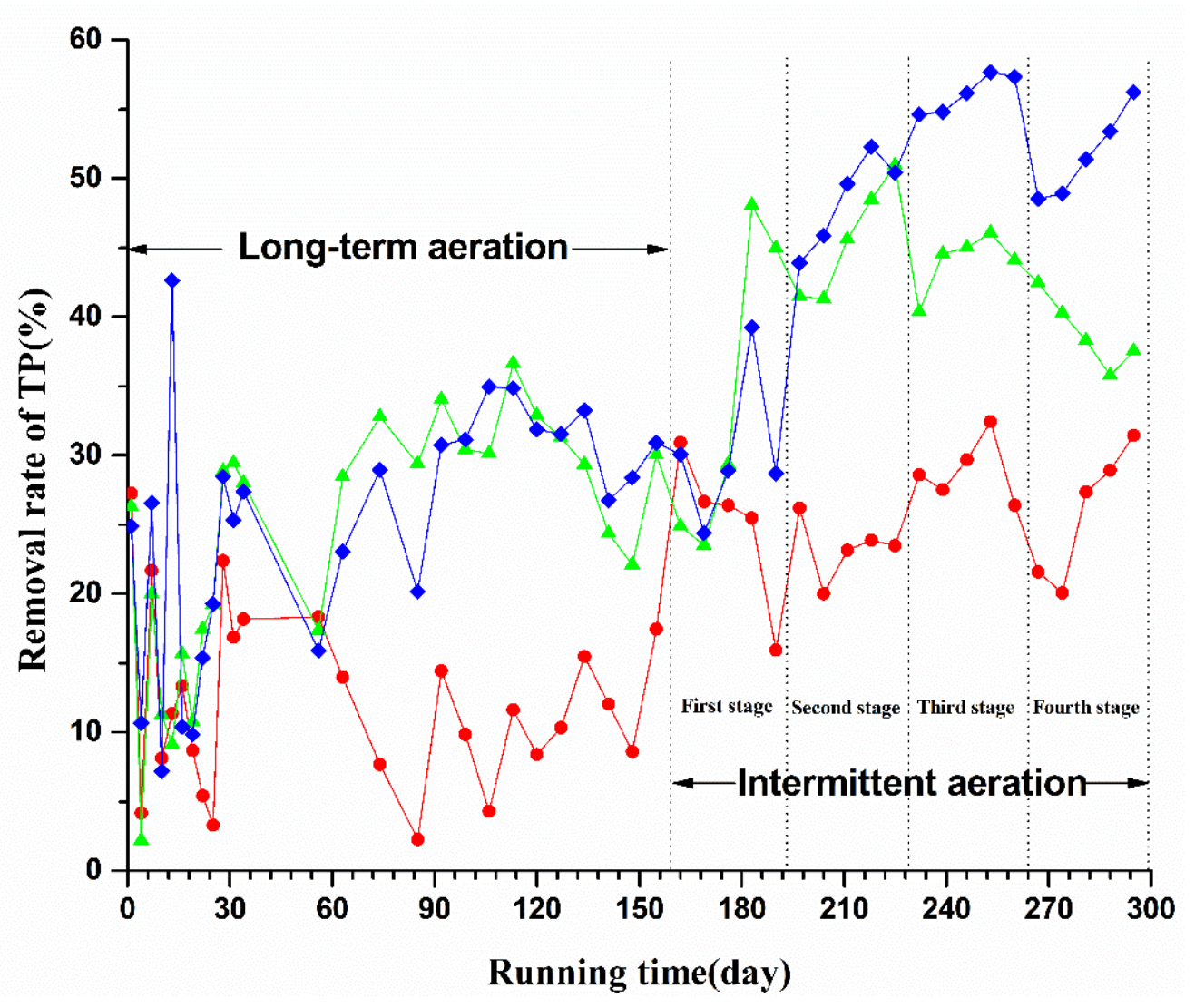

Figure 15. Changes of TP removal rate

During the four stages of intermittent aeration, the effluent TP concentration ranges as shown in Table 5. The average concentrations of four stages were $21.60 \mathrm{mg} / \mathrm{L}$, $22.12 \mathrm{mg} / \mathrm{L}, 20.91 \mathrm{mg} / \mathrm{L}, 21.78 \mathrm{mg} / \mathrm{L}$ in control reactor. The average concentrations of four stages were $19.04 \mathrm{mg} / \mathrm{L}, 15.67 \mathrm{mg} / \mathrm{L}, 16.46 \mathrm{mg} / \mathrm{L}, 17.97 \mathrm{mg} / \mathrm{L}$ in reactor one. The average concentrations of four stages were $20.12 \mathrm{mg} / \mathrm{L}, 14.86 \mathrm{mg} / \mathrm{L}, 12.91 \mathrm{mg} / \mathrm{L}$, $14.19 \mathrm{mg} / \mathrm{L}$ in reactor two. Therefore, the lowest effluent TP concentration of control reactor was the one of the third stage. The removal rate of TP was from $20 \%$ to $32 \%$ and the average removal rate was $26 \%$. The lowest effluent TP concentration of reactor one was the one of the second stage. The removal rate of TP was from $41 \%$ to $51 \%$ and the average removal rate was $46 \%$. The lowest effluent TP concentration of reactor two was one of the fourth stage. The removal rate of TP was from $48 \%$ to $57 \%$ and the average removal rate was $52 \%$. It can be concluded that for the removal of TP, the most suitable aeration conditions for control reactor, reactor one, reactor two were $1 \mathrm{~h}$ $20 \mathrm{~min} / 1 \mathrm{~h} 20 \mathrm{~min}, 1 \mathrm{~h} 20 \mathrm{~min} / 1 \mathrm{~h}, 1 \mathrm{~h} 20 \mathrm{~min} / 1$ h $20 \mathrm{~min}$.

Table 5. Effluent TP concentration ranges

\begin{tabular}{c|c|c|c}
\hline Stage & Control & Reactor one & Reactor two \\
\hline 1 & $20.46 \sim 23.19 \mathrm{mg} / \mathrm{L}$ & $15.18 \sim 23.22 \mathrm{mg} / \mathrm{L}$ & $17.96 \sim 21.62 \mathrm{mg} / \mathrm{L}$ \\
2 & $20.80 \sim 23.03 \mathrm{mg} / \mathrm{L}$ & $14.76 \sim 16.49 \mathrm{mg} / \mathrm{L}$ & $14.13 \sim 15.81 \mathrm{mg} / \mathrm{L}$ \\
3 & $20.54 \sim 21.48 \mathrm{mg} / \mathrm{L}$ & $16.10 \sim 17.15 \mathrm{mg} / \mathrm{L}$ & $12.45 \sim 13.16 \mathrm{mg} / \mathrm{L}$ \\
4 & $20.62 \sim 23.09 \mathrm{mg} / \mathrm{L}$ & $16.94 \sim 18.94 \mathrm{mg} / \mathrm{L}$ & $13.16 \sim 15.15 \mathrm{mg} / \mathrm{L}$ \\
\hline
\end{tabular}


Figure 16 shows that the TP concentrations of three reactors in the aeration tank appeared stable after a long period of aeration of three reactors. The concentration of TP in the aeration tank of control reactor reduced from $30 \sim 40 \mathrm{mg} / \mathrm{L}$ to $29 \mathrm{mg} / \mathrm{L}$ while that of reactor one and reactor two reduced to $26 \mathrm{mg} / \mathrm{L}$ and $27 \mathrm{mg} / \mathrm{L}$. After the intermittent aeration mode was converted to intermittent aeration, the TP concentration in the aeration tank reduced. In the third stage of intermittent aeration, the TP concentrations in the aeration tank of three reactors were minimum and those of control reactor, reactor one, reactor two were $24.53 \mathrm{mg} / \mathrm{L}, 20.33 \mathrm{mg} / \mathrm{L}, 12.00 \mathrm{mg} / \mathrm{L}$. It was indicated that the aeration tank played an important role in the removal of TP of the long-term aeration stage and the intermittent aeration stage. Since the operating modes of three reactors were changed from long-term aeration to intermittent aeration, the COD removal efficiency increased.

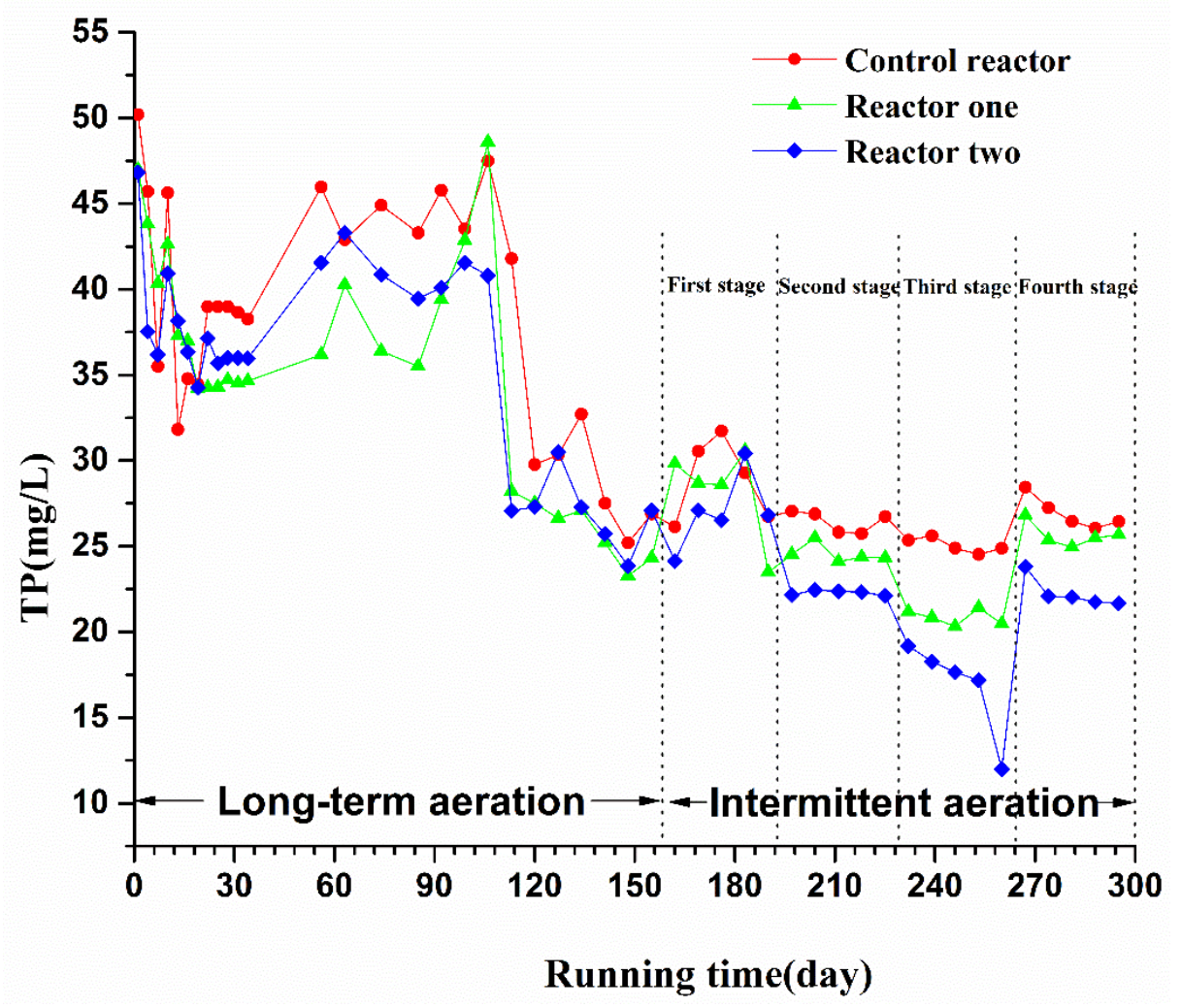

Figure 16. Changes of TP concentration in the aeration tank

Above all, after 120 days of long-term aeration, three reactors became a stable state. The removal of COD, $\mathrm{NH}_{3}-\mathrm{N}, \mathrm{NO}_{3}-\mathrm{N}, \mathrm{TN}$, TP of reactor one and two were better than those of control reactor, especially the removal of COD. In terms of the removal of COD, the capacity of reactor one was better than reactor two. In terms of the removal of $\mathrm{NH}_{3}-\mathrm{N}, \mathrm{NO}_{3}-\mathrm{N}, \mathrm{TN}, \mathrm{TP}$, the capacities of reactor one and two were basically alike. In the intermittent aeration mode, the most optimum aeration condition for reactor one was $1 \mathrm{~h} 20 \mathrm{~min} / 1 \mathrm{~h}$; reactor two was $1 \mathrm{~h} 20 \mathrm{~min} / 1 \mathrm{~h} 20 \mathrm{~min}$. Under the optimum conditions of three reactors, reactor two achieved the highest removal efficiency of $\mathrm{COD}, \mathrm{NH}_{3}-\mathrm{N}$, $\mathrm{NO}_{3}-\mathrm{N}, \mathrm{TN}, \mathrm{TP}$, which were better those of reactor one, and both of them were better than that of control reactor. 


\section{SS analysis}

Figure 17 shows that for the reactor one, the concentration of SS in the aeration tank reached the maximum of $2084 \mathrm{mg} / \mathrm{L}$ in the second stage of intermittent aeration. In this stage, the highest removal efficiency of $\mathrm{COD}, \mathrm{NH}_{3}-\mathrm{N}, \mathrm{NO}_{3}-\mathrm{N}, \mathrm{TN}, \mathrm{TP}$ was achieved. For the reactor two, the concentration of SS in the aeration tank reached the maximum of $1946 \mathrm{mg} / \mathrm{L}$ in the third stage. The highest removal efficiency of $\mathrm{COD}, \mathrm{NH}_{3}-\mathrm{N}, \mathrm{TN}$, TP was achieved in this stage.

As shown in Figure 17, the control always showed a steady trend from the beginning to the fourth stage, while the reactor one and reactor two showed an upward trend and tended to be gentle in the third to fourth stages. In the operating, the SS concentration reached a maximum in the second stage, at which stage the highest removal efficiency of $\mathrm{COD}, \mathrm{NH}_{3}-\mathrm{N}, \mathrm{NO}_{3}-\mathrm{N}, \mathrm{TN}, \mathrm{TP}$ were achieved. In the long-term aeration mode, the $\mathrm{SS}$ concentration from large to small was the control reactor, reactor two, reactor one, and the three reactors had significant differences $(\mathrm{P}<0.05)$; in the first phase and the second phase the concentration of reactor one were significantly higher than those of the control and reactor two $(\mathrm{P}<0.05)$. In the third stage, the SS concentration of the reactor two was the highest, and there was significant difference between the two reactors and the control and reactor one $(\mathrm{P}<0.05)$; The fourth stage was basically the same as the third stage. The reactor two had the highest concentration, the reactor one was the second, and the control was the lowest.

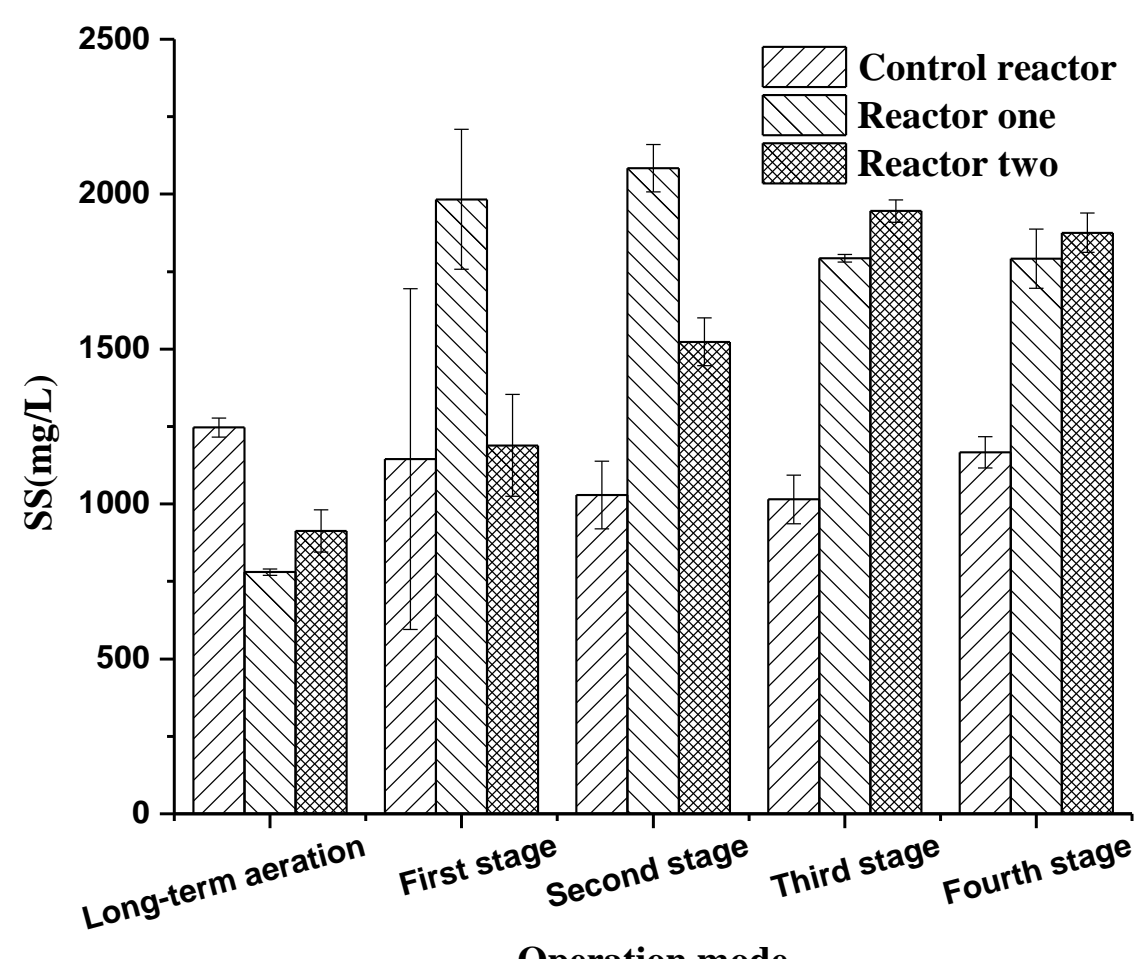

Operation mode

Figure 17. Changes of SS concentration in the aeration tank

\section{$\mathrm{SiO}_{2}$ analysis}

Figure 18 shows that the concentrations of $\mathrm{SiO}_{2}$ in reactor one's and reactor two's aeration tanks and reaction tanks were higher than those of control reactor. The reactor 
one achieved the highest $\mathrm{SiO}_{2}$ concentrations in its aeration tank and reaction tank, which were $0.218 \mathrm{mg} / \mathrm{L}$ and $0.310 \mathrm{mg} / \mathrm{L}$. It shows that silicates in reactor one and two were decomposed into $\mathrm{SiO}_{2}$. However, the $\mathrm{SiO}_{2}$ concentration in reactor one was the highest, which indicated that three kinds of silicate bacteria inoculated in Pellet (bacteria) played roles in the process of silicate decomposition.

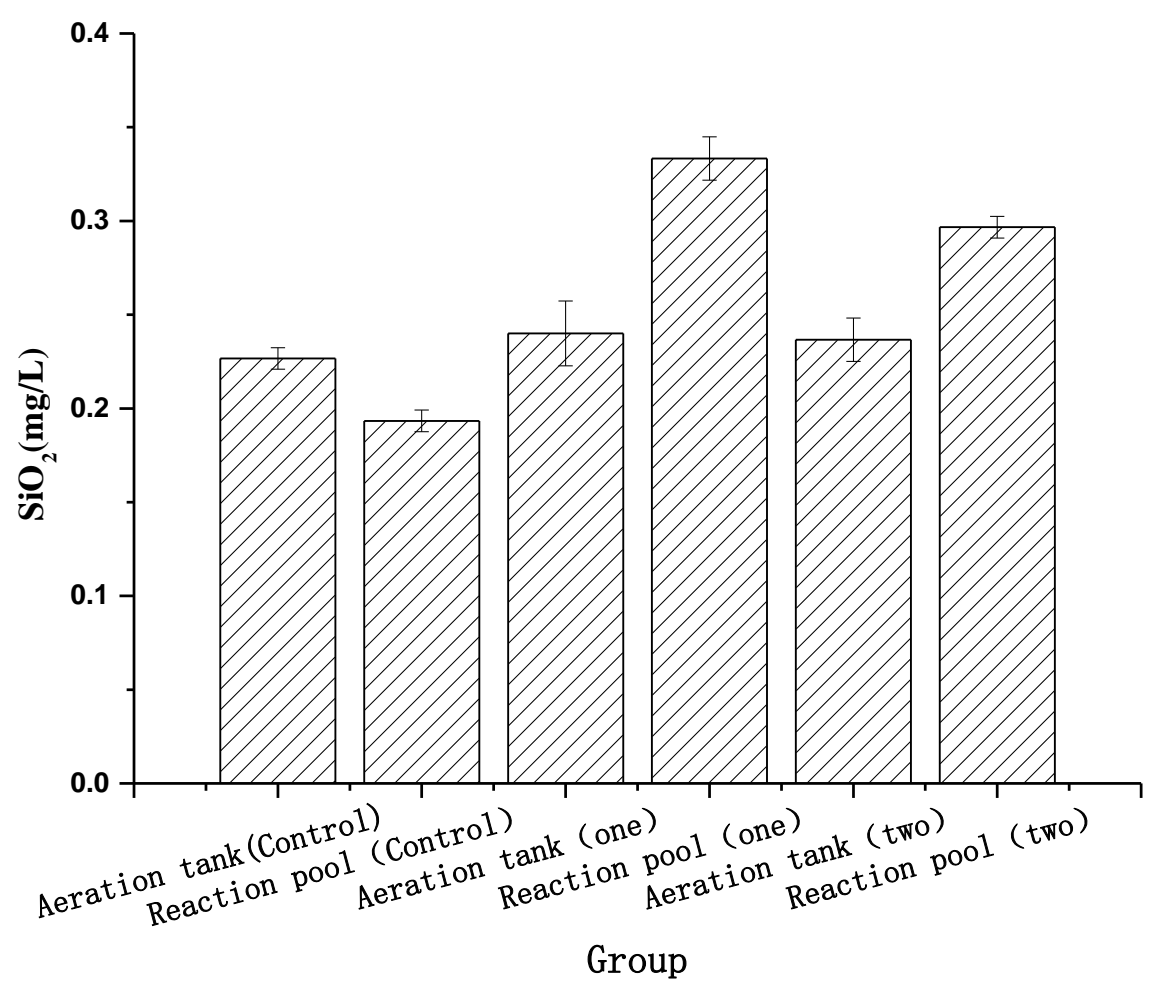

Figure 18. $\mathrm{SiO}_{2}$ concentration in the aeration tank and reactor in the 120th day

For the operation of three reactors, the removal efficiencies of reactor one and two on $\mathrm{COD}, \mathrm{NH}_{3}-\mathrm{N}, \mathrm{NO}_{3}-\mathrm{N}, \mathrm{TN}, \mathrm{TP}$ were better than those of control reactor under long aeration and intermittent aeration, which indicated that the removal efficiency of the high concentration organic wastewater is enhanced. Pellet (bacteria), Pellet and pumice have been aerated in the reaction tank of reactor one and reactor two for a long time. The main component of Pellet was peat soil and the content of organic matter in the peat soil was $70 \sim 80 \%$. The peat soil contains a large amount of water and incompletely decomposed plant residues, humus and a part of mineral matter and therefore there are a lot of humic precursors in Pellet. Figure 18 shows that the $\mathrm{SiO}_{2}$ concentrations in the reactor one and reactor two were higher than that of control reactor and thus the humic precursor and $\mathrm{SiO}_{2}$ existed in the reaction tank of reactor one and reactor two, which satisfies the condition of the soil bacteria culture system (Jiang et al., 2008) in the RBS system. The reaction tank of reactor one and two created a good environment for inducing, domesticating and screening the soil bacteria. Therefore, a large number of dominant soil bacteria are found throughout the whole reactor. In addition, Figure 18 shows that a decomposition process happens in the reaction tank of reactor one or reactor two. Silicate bacteria can decompose and oxidize the soil aluminosilicate minerals and release the elements such as $\mathrm{K}, \mathrm{Al}, \mathrm{Si}$ and some other 
elements (Zhang, 2000), which were the constant or trace elements for the growth of microbes. In this way, the reaction tanks of reactor one and two were provided a large amount of soil dominant bacteria and nutrients for the whole wastewater treatment system, so that the removal efficiency of the wastewater was enhanced.

He Wenyuan (He, 2008) has studied the effect of pumice in the process of bioactive water. The results of his study showed that the pumice had a large specific surface area and a lot of pores. It offers microorganism a place to live and can absorb organic compounds at the same time. It could release minerals, which can stimulate the growth of microbes. Therefore, it was possible because the minerals released from pumice in reactor one and two stimulate the growth of microbes which the treatment effects of reactor one and two were enhanced.

The removal capacity of three reactors for $\mathrm{COD}, \mathrm{NH}_{3}-\mathrm{N}, \mathrm{NO}_{3}-\mathrm{N}, \mathrm{TN}, \mathrm{TP}$ was improved after the operation mode was transferred from long-time aeration to intermittent aeration, especially removal capacity of $\mathrm{NH}_{3}-\mathrm{N}$. Therefore, the intermittent aeration is better than long-term aeration for three reactors. In the process of intermittent aeration, the maximum SS concentration of reactor one appears in the second stage of intermittent aeration, which corresponds to the best removal capacity of $\mathrm{COD}, \mathrm{NH}_{3}-\mathrm{N}, \mathrm{NO}_{3}-\mathrm{N}, \mathrm{TN}, \mathrm{TP}$ in this stage. The maximum $\mathrm{SS}$ concentration of reactor two appears in the third stage, which corresponds to the best removal capacity of COD, $\mathrm{NH}_{3}-\mathrm{N}, \mathrm{TN}, \mathrm{TP}$ in this stage.

After 120 days' long-term aeration, three reactors were reached the stable state. The effluents of $\mathrm{COD}, \mathrm{NH}_{3}-\mathrm{N}, \mathrm{NO}_{3}-\mathrm{N}, \mathrm{TN}$, TP concentrations in reactor one and two had little difference, especially the TN concentration and TP concentration, indicating that three kinds of silicate bacteria inoculated in the reactor pellet were less effective than the system itself in the removals of $\mathrm{COD}, \mathrm{NH}_{3}-\mathrm{N}, \mathrm{NO}_{3}-\mathrm{N}, \mathrm{TN}, \mathrm{TP}$, but played a role in the process of silicate decomposition.

\section{Conclusions}

By analyzing the water quality of COD, TN and TP, compared with DW, BW and BW (bacteria), two bioactive waters increased the removal rates of COD, TN and TP. And the main function of bioactive water was its own, including the structure of biologically active water. Bioactive water increased the decomposition of silicates and releases mineral elements that stimulate microbial activity. In the process of production of bioactive water, the structure of water molecules' changes, that is, the number of water molecules of the water clusters was reduced; the solubility of salt was increased, and the metabolic activity of microorganisms was enhanced. The bioactive water itself (including its own structure) enhanced the activity of the microorganisms, thereby enhancing the removal ability of the high-concentration organic wastewater.

Laboratory scale wastewater treatment reactor one and reactor two enhanced the removal efficiency of high concentration organic wastewater. The reactor had realized its own optimization after the operating mode transfers from long-time aeration to intermittent aeration. The most suitable aeration condition for reactor one was $1 \mathrm{~h}$ $20 \mathrm{~min} / 1 \mathrm{~h}$ while the most suitable aeration condition for reactor two was $1 \mathrm{~h} 20 \mathrm{~min} / 1 \mathrm{~h}$ $20 \mathrm{~min}$. According to our comprehensive analysis, reactor two achieved the best removal efficiency for high concentration organic wastewater. The optimum intermittent aeration condition of reactor two was $1 \mathrm{~h} 20 \mathrm{~min} / 1 \mathrm{~h} 20 \mathrm{~min}$ and the average removal rates of $\mathrm{COD}, \mathrm{NH}_{3}-\mathrm{N}, \mathrm{NO}_{3}-\mathrm{N}, \mathrm{TN}$, TP were increased by $3 \%, 21 \%$, 
$54 \%, 21 \%$ and $25 \%$ at this stage. The results show that bio-system was able to improve the treatment efficiency of high concentration organic wastewater and played an important role in the treatment reactor.

Acknowledgements. This work was supported by School Enterprise Cooperation Foundation of Yanbian University (project No. [2015]-7); National Natural Science Foundation of China (project No. 51368061).

\section{REFERENCES}

[1] Bao, S. D. (2000): Soil Agro Chemical Analysis (3rd ed.). - China Agriculture Press, Beijing.

[2] Bie, R. S., Li, B. X., Lu, H. L. et al. (2000): Deal with high concentration organic wastewater fluidized bed incinerator. - Boiler Manufacturing 1: 40-44.

[3] Chen, J. Q., Wang, H., Yang, X. L. (2002): Water Resources. - Science Press, Beijing.

[4] Chen, X. D., Li, Z. X., Meng, L. Y. (2008): Research progress of high concentration organic wastewater treatment technology. - Hebei Chemical Industry 31(12): 71-73.

[5] Du, H. Z., Fang, L. Q., Jiang, Y. et al. (1997a): Catalytic wet oxidation purification technology for refractory high concentration organic wastewater I. Development of wet oxidation catalyst with high activity and high stability. - Water Treatment Technology 23(2): 23-27.

[6] Du, H. Z., Fang, L. Q., Jiang, Y. et al. (1997b): Study on the catalytic wet oxidation purification technology of refractory high concentration organic wastewater II reaction process conditions. - Water Treatment Technology 23(3): 38-42.

[7] Ganigué, R., Volcke, E. I. P., Puig, S. et al. (2012): Impact of influent characteristics on a partial nitritation SBR treating high nitrogen loaded wastewater. - Bioresource Technology 111: 62-69.

[8] GB 11901 (1989): Water Quality Determination of Suspended Solids Weight Method. Standards Press of China, Beijing.

[9] Gilcreas, F. W. (1998): Standard Methods for the Examination of Waste and Wastewater. - APHA, Washington, DC.

[10] He, C. H., Zhu, M. Q., Liu, J. Q. et al. (2002): Extraction of caprolactam from aqueous ammonium sulfate solution in pulsed packed column using 250Y Mellapak packings. Chinese Journal of Chemical Engineering 10(6): 677-680.

[11] He, W. Y. (2008): Research on the Mechanism and Application of Bioactive Water. Tongji University, Shanghai.

[12] Huang, M., Zhu, Y., Xiao, J. et al. (2004): Evaluation of high concentration refractory organic industrial wastewater treatment technology. - Industrial Water Treatment 24(4): $1-5$.

[13] Jena, J., Kumar, R., Saifuddin, M. et al. (2016): Anoxic-aerobic SBR system for nitrate, phosphate and COD removal from high-strength wastewater and diversity study of microbial communities. - Biochemical Engineering Journal 105: 80-89.

[14] Jiang, Z. W., Lian, T. J., Hei, M. X. et al. (2008): Using natural purification RBS technology to treat high concentration organic sewage. - Exhibition and Seminar on Earth Saving of Practical Technology for Water Pollution Control, Fujian.

[15] Li, G. C., Zheng, X. Y., Piao, Z. X. et al: (2007): BTEX decomposition compound bacteria's separation and a decomposition characteristic. - Korea Institute of Industrial Waste 24(8): 689-695.

[16] Li, X. D., Yang, Y. (2002): New technology of wastewater biological treatment. - Fine and Specialty Chemicals 17: 19-21+6.

[17] Liu, F. R., Meng, L. H. (2008): SBR process characteristics and application development. - Science and Technology Information (Science Teaching and Research) 2: 29-30. 
[18] Liu, X. D., Chen, Y., Zhang, X. et al. (2015): Aerobic granulation strategy for bioaugmentation of a sequencing batch reactor (SBR) treating high strength pyridine wastewater. - Journal of Hazardous Materials 295(15): 153-160.

[19] Lu, J., Xu, G. T., Zhang, L. et al. (2001): Pharmaceutical industry wastewater treatment technology. - Industrial Water Treatment 21(10): 1-5.

[20] Qualls (1989): Persulfate Digest for Water Total $N$ and Total P. http://sisbl.uga.edu/qualls.html.

[21] Ren, A. (2000): Wastewater biological treatment technology and its research progress. Environment and Sustainable Development 4: 19-24.

[22] Rousseau, R. W. (1987): Handbook of Separation Technology. - John Wiley \& Sons, New York.

[23] Sun, P. S., Harada, Y., Yamazaki, K. (1999): Experimental study on catalytic wet air oxidation of high concentration organic wastewater. - Environmental Pollution and Prevention 21(1): 4-6.

[24] Wang, M. X., Liao, C. J. (2011): Biological treatment technology of high concentration organic wastewater. - Contemporary Chemical Industry 40(8): 820-823.

[25] Wang, Z. H., Sun, Y. H. (1995): Biotreatment technology for high concentration organic wastewater. - Jiangsu Environmental Technology 4: 29-32.

[26] Wu, Y. J. (2017): SBR sewage treatment technology application and development prospect. - Resource Conservation and Environmental Protection 5: 88-91.

[27] Yang, Y. Y., Dai, Y. Y. (1997): Complexation extraction method for the treatment of high concentration organic wastewater. - Modern Chemical Industry 3(3): 10-14.

[28] Zhai, H. W. (2014): Experimental Study on Treatment of Domestic Sewage by RBS. Changchun University of Science and Technology, Changchun.

[29] Zhang, J. S. (2000): Application technology of biological potassium fertilizer. Heilongjiang Science and Technology Information 2: 22.

[30] Zhang, X. (2014): Trend and governance system of water pollution in China. - Soft Science of China 10: 11-24.

[31] Zhao, Y. (2002): RBS technology for treatment of high concentration pig wastewater. Liaoning Urban and Rural Environmental Technology 22(1): 28-29.

[32] Zhao, Y., Zhu, F. H., Pang, G. L. et al. (2003): High concentration organic wastewater treatment technology. - Electric Power Environmental Protection 19(3): 46-48.

[33] Zhu, M. Q., Liu, J. Q., He, C. H. et al. (2001): Scale-up effect of pulsed sieve-plate column for recovering caprolactam from wastewater. - Proceedings of CKCSST01, Hangzhou. 